\title{
Amoritski identitet: simbol MAR u protoklinastim izvorima
}

\begin{abstract}
Polazišna je točka ovog rada problematika identiteta, podrijetla i migracije Amorita, koji se u znanstvenoj literaturi uglavnom predstavljaju kao glavni nositelji promjena prve polovine 2. tisućljeća pr. Kr., napose u Mezopotamiji i Levantu. Najraniji njihov naziv, koji se uglavnom prevodi kao „Amoriti“, jest sumerska složenica MAR. TU. Prvi se put javlja u tekstovima iz oko 2500. pr. Kr. Nakon sporadičnih zapisa u tekstovima druge polovine 3. tisućljeća pr. Kr., češće je srećemo u pisanim izvorima iz Treće urske dinastije (kraj 3. tisućljeća pr. Kr.). U ovom radu koncentrirat ćemo se na izvorni sumerski naziv, za koji se još uvijek ne zna kako se izgovarao, niti što je prvotno značio. Brojni su se sumerski nazivi, naime, još u 2. tisućljeću pr. Kr. zapisivali kombinacijom simbola koja nije imala izravne veze $\mathrm{s}$ fonetskom vrijednošću riječi, već je odražavala prvotnu ideju koja je stajala iza njih. Iz toga će se razloga u radu analizirati najraniji mezopotamski pisani izvori (kraj 4. tisućljeća pr. Kr.) i pokušati utvrditi što je simbol MAR značio institucijama za koje su se ti dokumenti zapisivali.
\end{abstract}

Migracije ukazuju, nekada kao i danas, na vrijeme nesigurnosti, kada određene skupine ljudi više nisu mogle preživjeti u svojim domovinama. Takva opsežnija kretanja mogu biti uzrokovana prirodnim nepogodama (duže doba suše, potresi, poplave...), političkim previranjima (smjena vladajuće klase) ili vanjskom invazijom (priljev novih skupina ljudi). Uzroci drevnih migracija teško se mogu sa sigurnošću utvrditi. Svjetlo nam pružaju rijetki pisani izvori urbanih središta, čiji je poredak uznemiren podaci iz arheoloških istraživanja i novija istraživanja o klimatskim oscilacijama u povijesti. Pisani izvori pružaju nam podatke o pojedinim sukobima i općenito o neprijateljima („barbarima“/migrantima) te uglavnom ne propituju uzroke kretanja tih ljudi. Te dokumente proizvela je središnja administracija u službi vladara, što znači da su bili i dijelom propagande tada aktualnog vladajućeg sloja. Stoga bi se svi ti izvori trebali interpretirati s gledišta tih urbanih, napadnutih vladajućih slojeva, a informacije koje oni daju nikako se ne smiju bespogovorno uzeti kao vjerodostojni podaci o karakteru migranata, njihovu izvorištu i namjerama. Interpretacije arheoloških nalaza mogu samo sa sigurnošću reći da je došlo do promjena, utvrditi karakter nove i razlike od stare situacije, ali ne mogu nepobitno utvrditi razloge promjene, a često ni sudionike događaja. Sve se navedeno posebno odnosi na povijesni razvoj Starog istoka. Rana povijest Starog istoka 
dugo je razdoblje ispunjeno uzdizanjem i propašću brojnih kultura. ${ }^{1}$ Gotovo sve velike prekretnice u povijesnom razvoju tog prostora povezane su s dolaskom novih ljudi. Jedna od njih dogodila se tijekom zadnje četvrtine 3. i početka 2. tisućljeća pr. Kr. Na Levantu to je vrijeme prelaska iz ranog u srednje brončano doba, a u Mezopotamiji se tada datiraju kraj sumerske i početak nove asirske i babilonske kulture. Te se promjene tradicionalno povezuju s dolaskom Amorita.

Glavni izvori za proučavanje navedene problematike pisani su i materijalni izvori. Dva su naziva u pisanim izvorima koja se prevode kao „Amoriti“ i „amoritsko“. Prvi je sumerski MAR.TU, koji se javlja u najstarijim izvorima, te kasniji akadski amurru(m). Pisani izvori o MAR.TU ljudima i zemlji/planinama zabilježeni su u južnomezopotamskim ${ }^{2}$ izvorima i onima iz sirijske Eble ${ }^{3}$ oko 2500. pr. Kr., oko 700 godina prije uspostave 1. babilonske (amoritske) dinastije. U tim stoljećima politička situacija u južnoj Mezopotamiji u nekoliko se navrata drastično promijenila. U najstarijim zapisima o MAR.TU osobama imena im većinom nisu amoritska. ${ }^{4}$ Nakon ranodinastičkog razdoblja južnomezopotamski izvori spominju sukobe i osvajanja MAR.TU prostora većinom unutar kraljevske propagande nove, semitske kulture Akadskoga Kraljevstva. Nakon raspada Akadskoga Kraljevstva, MAR.TU zemlja/planine prvi se put spominju u Gudeinim kraljevskim natpisima, u kontekstu ponovne uspostave trgovačkih veza sa susjednim područjima. MAR.TU osobe i područja brojniji su u pisanim izvorima Treće urske dinastije. U njima su osobe s amoritskim imenima, ili samo one opisane kao MAR.TU, bile aktivan dio državnog mehanizma, ali istodobno i „barbari“ s kojima se sukobljavaju na sjeverno-istočnim granicama kraljevstva. Najviše podataka imamo iz prve četvrtine 2. tisućljeća pr. Kr., kada se podaci o Amoritima, osim u mezopotamskim izvorima, pronalaze i u arhivu sirijskoga grada Marija. ${ }^{5} \mathrm{U}$ izvorima iz tog razdoblja većina vladara mezopotamskih gradova ima amoritska imena i jasno izražava „klansku“ srodnost (pripadnost

\footnotetext{
Od prvih pisanih izvora do Aleksandra Makedonskog prošlo je oko 3.000 godina.

2 O svim južnomezopotamskim izvorima 3. i prve četvrtine 2. tisućljeća pr. Kr. u kojima se spominju MAR.TU ljudi ili mjesto v. u de BOER 2014.

3 Za izvore iz Eble već je WILCKE 1969: 28 utvrdio da je čitanje drugog simbola iza MAR bilo $\mathrm{DU}_{2}$ (v. i ARCHI 2015: 354).

4 U arhivu iz Eble sačuvano je 15 imena osoba koje su opisane kao MAR.TU i samo se za jedno može reći da pripada amoritskom jeziku (v. ARCHI 2015: 355-359). Od mezopotamskih izvora samo je u jednom tekstu iz Šurupaka zapisano ime osobe koje je sumersko $\left(e_{2}-\mathrm{su}_{13}-\mathrm{ag}_{2} ; \mathrm{P} 011035\right.$, $\mathrm{r}$ II, 6,7).

5 Podaci iz Marija pružaju najdetaljniju sliku o životu sirijskih amoritskih skupina. Arhiv, međutim, sadrži dokumente iz samo 50 godina 19. stoljeća pr. Kr. (CHARPIN I ZIEGLER 2003) koji se odnose na ondašnju i onovremenu specifičnu geopolitičku situaciju. Neki od tih Amorita bili su stanovnici manjih ili većih gradova i sela, dok su drugi nazvani ha.na/hanûm i uglavnom su sa stadima lutali sirijskim stepama (GELB 1961: 37; DURAND 1998: 417).
} 
istoj „kući“). ${ }^{6}$ Nakon 200-tinjak godina političke rascjepkanosti, u Mezopotamiji uspostavljaju se dva kraljevstva pod vodstvom grada Ašura na sjeveru i Babilona na jugu, čiji su vladari u preuzetu sumersku ideologiju ugradili legitimitet „vladarâ koji su živjeli u šatorima“. ${ }^{7}$ Vladari sirijskih središta u prvoj četvrtini 2. tisućljeća pr. Kr. također imaju uglavnom amoritska imena. Levantska urbana središta u to se doba ponovo uzdižu. Ondje je arheološkim istraživanjima utvrđeno da je u drugoj polovini 3. tisućljeća pr. Kr. došlo do napuštanja i razaranja većine gradskih središta koja se ponovo ,urbaniziraju“ nakon cca 1900. pr. $\mathrm{Kr}^{8}$

Iz najranijih pisanih izvora nije jasno odnosi li se naziv MAR.TU na neku određenu skupinu ljudi koja živi na određenom području ili se, prema načinu života i/ili običajima, izdvaja od ostalih (nomadsko, polunomadsko ili na neki drugi način izdvojeno stanovništvo prema običajima, gospodarenju, jeziku). U pisanim izvorima taj se sumerski naziv koristi kao geografska odrednica, najčešće s determinativima KUR ,planina“ ili KI „mjesto“, kao kategorizacija ljudi ili ime božanstva (u imenima kanala, putova...). ${ }^{9}$

Nemam namjeru obraditi sve te izrazito kompleksne te za svako područje i vrijeme specifične uzroke i posljedice amoritske problematike. Koncentrirat ću se na najstarije izvore i situaciju u južnoj Mezopotamiji. Najraniji simboli kojima se označavaju ljudi, a ponekad i područje, jesu MAR i TU. Sumerogram MAR.TU u izvorima 3. i prve polovine 2. tisućljeća pr. Kr. uvijek se prevodi kao „Amoriti“ i „amoritsko“, ali se ne zna kako se čitao. ${ }^{10}$ Kombinacija simbola MAR.TU zapisivala se kao opis osoba i područja i u kasnijim, semitskim tekstovima. Velik broj drugih sumerskih naziva zapisivao se još barem tisućljeće nakon što je pismo postalo fonetsko u tom prvotnom obliku, za koji se zna da nije odgovarao fonetskoj vrijednosti riječi. ${ }^{11}$ Krenuvši od izvornog protoklinastog simbola MAR, istog i u sirijskim i mezopotamskim izvorima, namjeravam utvrditi koju je stvar/ideju predstavljao.

$6 \quad$ U tim izvorima Amoritima se nazivaju ljudi iz svih društvenih slojeva, ali postotak je takvog „amoritskog“" stanovništva u južnoj Mezopotamiji malen. To su većinom pripadnici viših, uglavnom vladajućih slojeva (v. de BOER 2014). U sumerskim tekstovima, koji se odnose na sirijski prostor i mogu se datirati oko 2000. pr. Kr., ima samo nekoliko amoritskih imena, dok u malobrojnim tekstovima iz Marija, koji su stariji od glavnog arhiva (prije 19. stoljeća pr. Kr.), nema niti jedno amoritsko ime (MICHALOWSKI 2011: 83).

7 O kraljevskoj ideologiji „kraljeva koji su vladali iz šatora“ v. WEISS 2017; WHITING 1995: 1235.

8 Sažetak dosadašnjih saznanja i daljnju literaturu v. u HOMSHER I CRADIC 2017: 268-276.

9 O božanstvu Martu/Amurru v. u BEAULIEU 2005.

10 Problem je što nema dvojezičnih tekstova u kojima se MAR.TU spominje. Neki od prijedloga čitanja bili su: Mardu, Martu, Ğardu (v. MARCHESI 2006: 11), ali niti jedan ne počiva na čvrstim lingvističkim temeljima. Izgovori pojedinih simbola sumerskog pisma i dalje su predmet rasprava jer se zna samo kako su se pojedini simboli kasnije izgovarali u babilonskom i asirskom jeziku.

11 Iz kasnijih dvojezičnih tekstova saznajemo da se pojedine skupine simbola nisu čitale fonetski, već je simboličko značenje sklopa tih simbola označavalo pojam, čija glasovna vrijednost nije 
Najprije ću ukratko predstaviti povijest istraživanja problematike te iznijeti glavne teorije jer ću pokušati utvrditi može li se sastavni dio sumerograma, kojim su se prvotno označavali „Amoriti“, na neki način dovesti u vezu s pretpostavljenim izvornim područjem Amorita ili s pretpostavkom da su bili nomadi.

\section{Amoriti u dosadašnjoj historiografiji i problematika amoritskog identiteta}

O Amoritima se u znanstvenim krugovima vode rasprave još od početka prošloga stoljeća. Jedan su od naroda koji se često spominje u Bibliji pa su i prvotne interpretacije njihove uloge u povijesti Starog istoka bile pod tim utjecajem. Neke „biblijske“ paradigme i danas se provlače znanstvenom literaturom. Jedna je od takvih i amoritski identitet. Glavni je problem taj da se a priori smatra da je postojala etnički definirana zajednica Amorita ${ }^{12}$. Poimanje jedinstvenog amoritskog etnika dodatno su poduprli mezopotamski tekstovi, pogotovo oni iz prve četvrtine 2. tisućljeća pr. Kr. Time je stvorena čvrsta paradigma o Amoritima koji su kao nomadi krajem 3. i početkom 2. tisućljeća pr. Kr. osvajali urbana središta u Mezopotamiji i na Levantu.

Smatra se da su Amoriti bili ljudi zapadnosemitskog podrijetla koji su dijelili zajednički etnički, lingvistički i kulturni identitet. ${ }^{13}$ Uglavnom se bez ikakvog problematiziranja uzima da osobe sa zapadnosemitskim imenima (pripisanim amoritskom jeziku) i one okarakterizirane kao MAR.TU (iako imaju neamoritska imena) pripadaju jedinstvenom etniku. Također se donedavno bez pogovora preuzimao podatak iz nekih pisanih izvora da su bili nomadi. ${ }^{14}$ Prema većini interpretacija, bili su grupirani u klanove, ali su ipak ostali koherentna zajednica koja je imala zajednički ekonomski interes. Pojedine grupe postupno su se infiltrirale u glavna središta Mezopotamije i Levanta. ${ }^{15}$ Nomadsko podrijetlo Amorita posebno je problematično jer se dovode u vezu sa srednjobrončanodobnom kulturom na Levantu, kojoj je glavna karakteristika izrazita urbani-

odgovarala glasovnoj vrijednosti klinastih simbola. Primjerice, PA TE SI čitalo se ensi, '(gradski) namjesnik'. Drugi primjeri mogu se vidjeti u dokumentu CDLI Preferred Sign Readings (https://cdli.ucla.edu/tools/sign_readings/index.php).

12 Poput Hetita, koji se spominju u Starom zavjetu, Amoriti su najvjerojatnije preuzeti iz književne konstrukcije asirsko-babilonskih literarnih tekstova prve polovine 1. tisućljeća pr. Kr., kao i njihove geografske terminologije (Amurru i Hatti) za cijelo područje Levanta = Zapad (LIVERANI 1992: 120; UEHLINGER 2000).

13 Važno je napomenuti da do sada nije pronađen niti jedan tekst na amoritskom jeziku, koji poznajemo isključivo prema osobnim imenima i malobrojnim posuđenicama u babilonskom jeziku (MICHALOWSKI 2011: 83).

14 Najpoznatiji i najčešće citirani izvor jest sumerska priča iz starobabilonskog razdoblja Vjenčanje Martua (ETCSL 1.7.1), gdje je Martu opisan kao necivilizirani nomad.

15 V. GZELLA 2014: 25. 
zacija. ${ }^{16}$ Amoritskim skupinama pripisuju se destrukcija urbanih središta ${ }^{17}$ te privremena ,ruralizacija i nomadizacija“ levantskoga prostora. ${ }^{18}$ Predloženi su različiti mehanizmi pretpostavljenih kretanja amoritskih skupina. Donedavno dominantna početna hipoteza bila je da se dogodila vojna invazija. ${ }^{19}$ Srodne teorije u prvi plan stavljaju porast stanovništva kao glavni okidač migracija. ${ }^{20}$ Posljednjih desetljeća učestala su istraživanja kilimatskih oscilacija i sve više imaju važnu ulogu u interpretaciji uzroka i posljedica propasti starih kultura. ${ }^{21}$

U žarištu svih novijih interpretacija pitanje je amoritske migracije i identifikacija amoritskog identiteta. Budući da najraniji pisani izvori domovinu MAR.TU ljudi i područje MAR.TU planina bilježe negdje u današnjoj sjeveroistočnoj Siriji, ${ }^{22}$ za utvrđivanje uzroka i karaktera eventualne migracije ključna su pitanja kada ondje dolazi do promjena. Stoga većina znanstvenika, prvenstveno arheologa, pokušava identificirati amoritski identitet prije promjena na tom prostoru. ${ }^{23}$ Glavni je problem

16 Fortifikacije, monumentalna gradnja i ukop pokojnika unutar grada (v. u HOMSHER I CRADIC 2017: 268-276). Objašnjenje ponovne urbanizacije levantskog prostora za srednjega brončanog doba migracijom prvenstveno amoritske populacije (sa sirijskoga prostora) provlači se u znanstvenoj literaturi već gotovo cijelo jedno stoljeće (v. ALBRIGHT (1922; 1935; 1965); KENYON (1957; 1966); AMIRAN (1960), PARR (1968); DEVER ET AL. (1970); KAPLAN (1971; 1975); DEVER (1985), ali i BURKE (2014a; 2014b; 2017)).

17 Arheološkim istraživanjima potvrđena je destrukcija gotovo svih urbanih središta na kraju ranog brončanog doba.

18 Predvodnici te paradigme svakako su bili KENYON $(1957 ; 1966)$ i DEVER ET AL. (1970). Međutim, pogled na ovu problematiku promijenio se jer je utvrđeno da je do razaranja i napuštanja urbanih središta na Levantu došlo već oko 2500. pr. Kr. (negdje i prije, HÖFLMAYER, DEE, GENZ I RIEHL 2014).

19 Prve teorije temeljile su se prvenstveno na pisanim izvorima iz vremena Treće urske dinastije, ali i ti podaci bili su selektivno izneseni. Jedan od prvih koji se time bavio bio je BAUER (1926), a bila su utjecajna i djela KENYON (1966) i KAPLAN (1971).

20 Od njih je u novije vrijeme najrazrađenija ona BUCCELLATIJEVA(2008). Smatra da zajedničke karakteristike ukazuju na to da je postojala neka vrsta amoritske političke unije koja je, prema njegovu mišljenju, moguće bila vezana s oblikom ,industrijskog“" nomadstva ili, kako je u radu razložio, „seljaci postaju nomadi pa zatim urbano stanovništvo“.

${ }^{21}$ Za ovo razdoblje ključnu ulogu u raznim novim interpretacijama ima takozvani 4.2 kya climate event (konvencionalan način pisanja datacija pri geološkim analizama i generalno označava 'prije xx tisuća godina' - kilo-years ago). Mogao bi se sumarno opisati kao sušni period koji je zahvatio širi euroazijski prostor i koji je, barem na Starom istoku, trajao od 2200. do 1900. pr. Kr. Izneseno je i niz kritika na interpretacije koje bez pogovora prihvaćaju da je cijelo područje bilo pogođeno dugotrajnom sušom jer neki od rezultata takvih analiza ukazuju da se takve drastične klimatske oscilacije nisu svuda događale. Više o problematici interpretacije 4.2 kya suše v. u HOMSHER I CRADIC 2017: 264-267; WEISS 2017.

22 Vjerojatno Djebel Bišri planine (v. detaljnije u LÖNNQVIST I TÖRMÄ 2004; LÖNNQVIST 2010). Arheološki ostaci ukazuju na klansku organizaciju stanovništva na tom prostoru, ali ih se ne može sigurno povezati s Amoritima (LÖNNQVIST 2010: 125).

23 Radna je hipoteza većine arheologa, pa i onih koji istražuju kulture Starog istoka, da se pripadnost određenoj etničkoj grupi reflektira u specifičnim karakteristikama materijalne kulture (tipologija 
činjenica da se arheološki ne može izdvojiti konkretna kultura u pretpostavljenoj amoritskoj pradomovini. ${ }^{24}$ Stoga nije moguće arheološki utvrditi kretanja stanovnika navedenog prostora. Većina arheoloških studija kreće od pretpostavke da su Amoriti bili prvotno pastirsko-nomadske skupine. ${ }^{25}$ Znanstvenici koji se prvenstveno bave pisanim izvorima usredotočeni su na tekstove i razne mogućnosti njihovih prijevoda pa rijetko spominju rezultate arheoloških istraživanja. Rezultat je da se uglavnom bave problemima saveza i sukoba pojedinih mezopotamskih gradova i njihovih vladara s pojedincima amoritskih imena.

Jedini dokazi o postojanju amoritskog identiteta zabilježeni su u pisanim izvorima urbanih središta koji su administrativnog karaktera ${ }^{26}$ ili su dio kraljevske propagande. ${ }^{27}$ Nikada ne smijemo smetnuti s uma da su navedeni pisani izvori produkt službene administracije kojoj nije bilo bitno utvrditi tko su MAR.TU stvarno bili, već samo što su predstavljali za središnju upravu. Nekritičko prihvaćanje podatka da su Amoriti bili značajan društveni i/ili politički faktor u Mezopotamiji i na Levantu već je dugo kamen spoticanja mezopotamske historijske znanosti, ${ }^{28} \mathrm{koji}$ na različite načine pokušavaju razriješiti povjesničari, arheolozi i lingvisti. Brojni su autori već ukazali na nekritičko preuzimanje podataka iz pisanih izvora, koji se primjenjuju na složene društveno-kulturne promjene na Levantu i u Mezopotamiji. ${ }^{29}$ Sve se više preispituje postojanje amoritskog etnika. ${ }^{30} \mathrm{Je}$ li postojao amoritski identitet prije vremena amoritskih vladara? Ako jest, je li bio samo konstrukt urbane ideologije mezopotamskih vladajućih slojeva? Kao što su i Michalowski ${ }^{31}$, a potom Homsher i Cradic ${ }^{32}$ utvrdili, pisani izvori stvaraju amoritsku ideologiju

keramičkog i metalnog asortimana, pogrebni običaji, tipovi stambene i javne arhitekture...) i da je distribucija tih kulturnih elemenata dokaz kretanja pripadnika te etničke skupine.

LÖNNQVIST 2009: 52, 53.

Takva interpretacija Amorita temelji se prvenstveno na južnomezopotamskim izvorima i izjednačavanju kasnijih imena osoba koje se kao polunomadi spominju u tekstovima iz Marija (oko 1800. pr. Kr.).

26 Zapisano je samo ime i/ili status osobe.

27 Kraljevski natpisi i dvorska korespondencija. U tim izvorima MAR.TU spominje se ili kao područje s kojim se trgovalo ili je opis neprijatelja, „Drugog“, $u$ vremenima sukoba na mezopotamskim granicama u izvorima tisućljeća pr. Kr.

28 BAHRANI 2006: 55.

29 Neki od autora koji su ukazivali na problematiku te nekritičke analize i pisanih i materijalnih izvora jesu: CAMPBELL 1999; JOHNSON 1999; CAMPBELL i FLETCHER 2010; KARSGAARD 2010; PHILIP 2011; MICHALOWSKI 2011.

30 Tako se u nekim studijama naglasak stavlja na amoritski političko-ideološki identitet koji se polako izgrađivao krajem 3., a kristalizirao početkom 2. tisućljeća pr. Kr. RISTVET (2012) „amoritskim“ shvaća konstruirani identitet, kojem je glavni cilj bio stopiti razne tradicije sa svrhom da se stvori zajednički, panmezopotamski identitet i da su svi amoritski vladari vladali izrazito multietničkom populacijom.

MICHALOWSKI 2011.

32 HOMSHER I CRADIC 2017: 267. 
koja se mijenja kroz vrijeme (te različite geopolitičke i društvene odnose) i koja je mogla imati društvenu, političku, religijsku ili ekonomsku podlogu pa stoga praktički nije moguće utvrditi koji je bio, ako je uopće postojao, izvorni etnički ili socijalni identitet osoba u izvorima nazvanim Amoritima.

\section{Simbol MAR u protoklinastom korpusu tekstova ${ }^{33}$}

Protoklinasto je ideografsko pismo i iako su prve pločice pronađene još u prvoj polovini 20. stoljeća, tek se od 1990-ih godina ozbiljno pristupilo dešifriranju početne faze mezopotamskog pisma. ${ }^{34}$ Najveći broj pločica s protoklinastim tekstovima pronađen je u gradu Uruku, u slojevima hramskog kompleksa božice Inane (Eanna) ${ }^{35}$. Pločice su, na temelju paleografske analize, podijeljene na dvije faze: sloj Uruk IV. (prva faza pisma) i Uruk III. (druga faza pisma). Pločice iz prve faze zasad su pronađene samo u Uruku, iako ima i onih kojima se ne može utvrditi podrijetlo. Pločice druge faze pronađene su i na drugim lokalitetima (Djemdet Nasr, Ešnuna, Kiš, Larsa, Ukair, Uma; Karta 1).

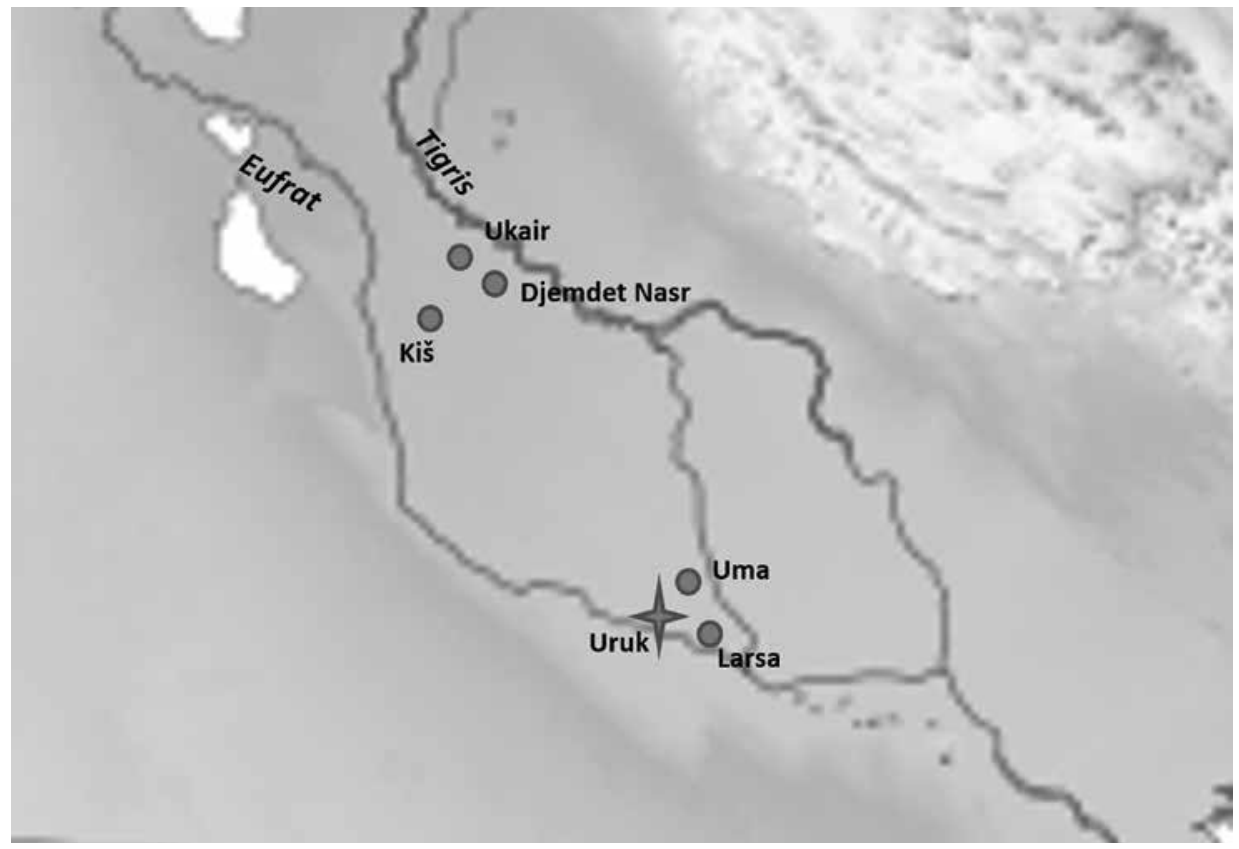

1. Karta južne Mezopotamije s lokalitetima uručkog razdoblja. Crvenim točkama označeni su lokaliteti na kojima su pronađene protoklinaste pločice.

\footnotetext{
33 Svi protoklinasti tekstovi pregledavali su se u The Cuneiform Digital Library Initiative (https:// cdli.ucla.edu/).

34 Sažetak tijeka dešifriranja protoklinastog pisma v. u ENGLUND 2004: 1.

35 GLASSNER 2003: 46.
} 
$\mathrm{U}$ administrativnim dokumentima uglavnom se u prvom unosu na aversu navodio osnovni predmet poslova, iako u manjim dokumentima taj dio često nedostaje. Nakon toga slijede unosi pojedinih transakcija u kojima se zapisuju (ako je riječ o poslovima s različitim proizvodima, ali za istu svrhu ili instituciju) vrste proizvoda. Često su zapisani i nadležni administratori ili institucije, vrste poslova za koje se doznačuju ili mjesto podrijetla/odredišta. Ponekad veći dokumenti na kraju zapisa pojedinih skupina transakcija imaju unos bez numeričke notacije, koji je vjerojatno naznačivao instituciju ili karakter tog dijela dokumenta. Taj je unos ponekad ponovljen i u konačnom obračunu na kraju dokumenta, ali ovaj put s numeričkom notacijom (zbrojem unosa na koje se odnosio, koje je „potpisao“). Na samom kraju završni je obračun u kojem su zapisane najrelevantnije stavke iz prethodnih unosa. To su uglavnom vrsta poslova, titula zaduženog administratora i nadležna institucija ili mjesto kojem su navedeni poslovi namijenjeni. Ponekad je na kraju zapisan i završni „potpis“ bez ikakve numeričke notacije. To je vjerojatno dodatna informacija o konačnom obračunu, naglašavanje glavne nadležne institucije ili utvrđivanje svrhe bilježenih poslova. ${ }^{36}$

U najranijim protoklinastim tekstovima simbol MAR je verzija simbola $\mathrm{GA}_{2 \mathrm{a} 2} \mathrm{~s}$ dodanim urezom s desne strane (Slika 1). $U$ simbol GA ${ }_{2 \mathrm{a} 2}$ najčešće su se upisivali razni simboli proizvoda koji su inače, prema pisanim izvorima, osnova ekonomije za to razdoblje (riba i prerađevine, goveda, koze, rude, kamen, aromatične trave), kao i simboli raznih ,institucija“ kojima su možda pripadali (LAGAB, NUN, TI...) pa se može pretpostaviti da je simbol trebao predstavljati neku vrstu skladišta. U simbol MAR se također upisuju drugi simboli, ali samo onaj za ječam (ك̌E) i simbol LAGAB, koji se odnosio na neku instituciju ili područje. U kasnijim tekstovima pisanim na sumerskom jeziku riječ mar, zabilježena simbolom MAR, u različitim kontekstima i vremenima ima različita značenja pa se tako navode: 'lopata', 'kola', 'mjesto', 'nalet', 'vijati/razbacati (žito)', 'crv/parazit'. ${ }^{37}$

Simbol MAR zapisan je u 112 administrativnih dokumenata i 12 leksičkih listi. U tekstovima prve faze pojavljuje se na 27 pločica. Od toga četirima se ne može utvrditi podrijetlo, dok su ostala 23 sigurno iz grada Uruka. Na jednoj pločici nepoznatog podrijetla $^{38}$ može se utvrditi da se simbol MAR pojavljuje u kontekstu poslova sa simbolom KIŠ (unos je MAR UDU), ${ }^{39}$ na jednoj je u obračunu zapisano da se radi o DIN. ${ }^{40}$ Što se tiče pločica iz Uruka, za jednu se ne može ništa konkretno zaključiti jer je sačuvan jedino unos MAR PAZATU 699. ${ }^{41}$ U najviše njih (osam) simbol MAR

36 O raznim tipovima pisanih dokumenata v. u NISSEN, DAMEROW I ENGLUND 1993: 19, 20, 21.

37 LMSZ: 422, 423.

38 P411875, P252173, P252177, P006325.

$39 \quad \mathrm{P} 252177$.

$40 \mathrm{P} 006325$.

$41 \mathrm{P} 002485$. 


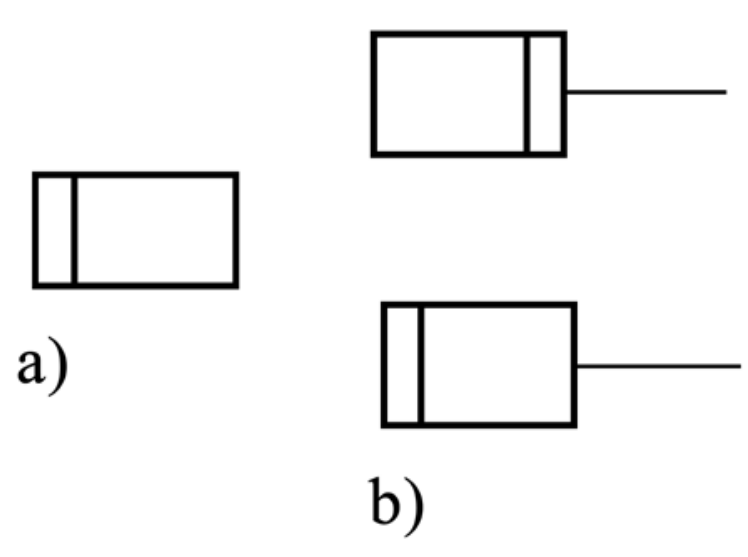

1. Protoklinasti simboli MAR - b) (preuzeto s https://cdli.ucla.edu/dl/ineart/P001927_l. jpg, https://cdli.ucla.edu/dl/lineart/P001993_l.jpg i https://cdli.ucla.edu/dl/lineart/ P002048_l.jpg, posjet 19.1.2020.) i GA2 - a) (preuzeto s https://cdli.ucla.edu/dl/lineart/P001952_l.jpg, posjet 19.1.2020.)

zabilježen je u dokumentima o poslovima s ovcama. ${ }^{42} \mathrm{Na}$ četirima pločicama bilježe se poslovi s ječmom. Na dvjema je simbol ŠE i osnovna namirnica u završnom obračunu, na trećoj bilježe se poslovi s ječmom i ovcama, a na četvrtoj ${ }^{43}$ se poslovi s ječmom obavljaju za DARA ${ }_{3} \mathrm{x}\left|\mathrm{KAR}_{2} . \breve{S} E\right|$. Na četirima pločicama simbol MAR je u dokumentima koji bilježe poslove sa simbolima $\mathrm{TUN}_{3}, \mathrm{KU}_{3}$ i ŠELU. ${ }^{44}$ I ti bi se poslovi mogli uvrstiti u poslove s ječmom i ovcama, točnije, pređom vune jer je simbol ŠELU zapravo kombinacija simbola ŠE i $\mathrm{SIG}_{2}{ }^{45} \mathrm{Simbol} \mathrm{KU}_{3} \mathrm{u}$ kasnijim se sumerskim tekstovima prevodi kao 'srebro' pa se možda u ovim dokumentima radi o kupnji ili prodaji ječma za pređu vune na mjestu ili za instituciju (?) TUN ${ }_{3}$. $\mathrm{U}$ trima dokumentima zabilježeni su poslovi s kravama i volovima $\left(\mathrm{AB}_{2} \mathrm{i} \mathrm{GU}_{4}\right){ }^{46}$ a u dvama su poslovi okarakterizirani simbolom $\mathrm{HI}^{47}$. Dva puta je simbol MAR zapisan u tekstovima o radnoj snazi. ${ }^{48}$ Još jedan dokument bilježi raspodjelu por-

\footnotetext{
42 P000804, P001236, P001414, P001552, P004017. U trima se slučajevima bilježi ječam (P000836; P001264; P001283), i to na malim pločicama na kojima je zapisan samo jedan redak. Unutar njega zapisan je i simbol za ovcu i onaj za ječam, uz simbol MAR. Na svim trima zabilježen je i simbol koji najvjerojatnije predstavlja odgovornog službenika i instituciju za koju se zapisani poslovi obavljaju (NESAG ${ }_{2}$; GURUŠDA MUŠ 3 ; KISAL EN).

$43 \quad$ P001332.

44 P001919, P001920, P001931, P001993.

45 Simbol $\mathrm{SIG}_{2}$ označava krug s dvama redovima usporednih crtica, koji se u kasnijim sumerskim tekstovima izgovarao siki, a to je riječ za 'vunu' (LMSZ: 584, 587).

46 P000958, P001568, P004112.

$47 \mathrm{P} 002048, \mathrm{P} 004112$.

48 P001284, P001799. Jedanput su u pitanju radnice, SAL, a jedanput općeniti simbol SAG.
} 
cija hrane GAR, ali nije naznačeno kome. ${ }^{49}$ Od kombinacija simbola koji su česti u kasnijim tekstovima najbrojnija je MAR ŠE (šest puta). ${ }^{50}$ Slijedi AN MAR (tri puta) ${ }^{51}$, pa MAR PA (dva puta). ${ }^{52} \mathrm{U}$ jednom dokumentu zapisan je simbol PAP. ${ }^{53} \mathrm{Na}$ dvjema pločicama kombinacija je ŠELU MAR ŠU. ${ }^{54}$ Simboli MAR APIN zajedno se javljaju samo na jednoj pločici. ${ }^{55} \mathrm{U}$ dokumentima iz Uruka, na kojima je zapisan simbol MAR, uopće nema simbola za ptice (DAR i MUŠEN). ${ }^{56}$

U tekstovima druge faze MAR je zapisan na 109 pločica. U Uruku pronađeno ih je u 35, iz Ume potječe vjerojatno 21, iz Larse 15, Djemdet Nasra 5, iz Ukaira 2, iz Kiša 1, a ne može se utvrditi podrijetlo 30 pločica.

Od 35 pločica iz Uruka, na kojima je simbol zapisan, 21 je leksička lista. Među administrativnim dokumentima najbrojnije su pločice kojima se određuju nadnice radnicima (sedam). ${ }^{57} \mathrm{Na}$ trima su pločicama poslovi možda povezani s pripremom polja. ${ }^{58}$ Pet je pločica koje su previše uništene da bi se utvrdili poslovi koji su na njima zabilježeni. ${ }^{59}$ Najbrojnija je kombinacija simbola MAR APIN (3 dokumenta), ${ }^{60}$ nakon nje AN MAR (2 dokumenta) ${ }^{61}$ i MAR ŠE (1 dokument). ${ }^{62}$ Najbrojniji unosi simbola MAR nalaze se u leksičkim listama. Po šest primjeraka sačuvano je u leksičkoj listi $\mathrm{Lu}_{2} \mathrm{~A}^{63}$ (MAR APIN ${ }^{64}$ ) i onoj „Arhajskog metala“ $\left(\mathrm{TAK}_{4} \mathrm{MAR}\right),{ }^{65}$ a simbol zapisan u kombinaciji MAR ŠE može se pripisati listi

\footnotetext{
$49 \quad \mathrm{P} 002495$. se na dvjema pločicama (P005331, P005335 - dijeli se ječam za GU i GI GAN $_{2}$ ) odnosi na radnike u KU ŠIM (vjerojatno pivovari). Na jednoj označava radnice (P005386, možda za pripremu polja), a na drugoj radno sposobne osobe (AL, P004313).

58 Na jednoj su učestalo zapisani SI, $\mathrm{SI}_{4}$, APIN, ANŠE, SAR (ali nema simbola ŠE) i više je puta

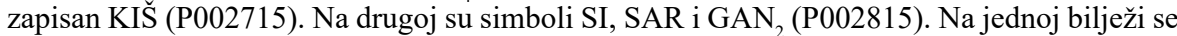
podjela porcija hrane $\left(\mathrm{GU}_{7}\right)$, najvjerojatnije radnicama. U konačnom je obračunu opis poslova $\mathrm{SI}_{4} \mathrm{AZ}(\mathrm{P} 005386)$.

59 P002590 (unos je MAR), P002179 (unos je AN MAR), P004476 (unos je MAR), P004313 (unos je EN MAR ŠA ), P002670 (unos je ZATU694 MAR ŠE DA). P005331, P005335, P005386.

61 P002179, P001063 (u obliku AN MAR PA, u kontekstu porcija hrane GAR radnicama).

$62 \mathrm{P} 002670$

63 P000247, P000604, P000207, P000236, P000554, P000557.

64 Simbol APIN ikonografski jasno označava plug s dodatkom kutijica za sjeme (inovacija 4. tisućljeća pr. Kr.). U kasnijim sumerskim tekstovima taj se simbol uglavnom prevodi kao 'plug' (LMSZ: 61, 62).
} 
„Drveća“ ${ }^{66}$, „geografskih toponima“67 i „Tributa“. ${ }^{68}$ Jednom je zapisan u Listi svinja.$^{69}$ Ostali se unosi ne mogu pripisati niti jednoj do sada poznatoj listi. ${ }^{70}$

U korpusu pripisanom gradu Umi simbol MAR pronađen je na 21 pločici s administrativnim tekstovima. Na četirima ${ }^{71}$ ne može se utvrditi o kakvim se poslovima radi. Najviše dokumenata sa simbolom MAR bilježi razne poslove s ovcama, njih devet. ${ }^{72}$ Nakon njih najbrojniji su oni sa simbolom KIŠ u krajnjem obračunu (4 dokumenta). ${ }^{73}$ Dvije pločice bilježe poslove $s$ ječmom ${ }^{74}$, a jedna poslove s tekstilom $\left(\mathrm{TUG}_{2}\right){ }^{75}$ Još se na jednoj pločici, ${ }^{76}$ kojoj je u završnom obračunu zapisano DAR MAR, na temelju unosa na prednjem dijelu bilježe radnice (SAL). Samo su dva dokumenta o poslovima vezanim uz ječam. ${ }^{77} \mathrm{U}$ Umi je simbol MAR najčešće zapisan u kombinacijama koje se nikada ne javljaju u Uruku: I MAR (četiri puta) ${ }^{78}$ i DAR/MUŠEN MAR (tri puta). ${ }^{79}$ Najučestalija kombinacija simbola u Uruku, MAR APIN, u Umi je zapisana samo jedanput ${ }^{80}$ ali zbog poretka simbola APIN je vjerojatno dio pojma sa simbolom $\mathrm{NAM}_{2}{ }^{81}$ Kombinacije MAR ŠE uopće nema, kao ni MAR PA, ali je na dvjema pločicama zapisana kombinacija MAR PAP ${ }^{82}$ Zajedno sa simbolom AN pojavljuje se u unosu samo na dvjema pločicama, i to na jednoj uz simbol MA, ${ }^{83} \mathrm{a}$ u drugom slučaju s DA. ${ }^{84}$

\footnotetext{
P000519, P000641, P000103, P000262, P000683, P000258.

$66 \mathrm{P} 000665$.

$67 \quad \mathrm{P} 000201$.

$68 \mathrm{P} 000517$.

69 P000456 (MAR ŠUBUR).

70 P000197, P000547, P000585, P000610, P000694.

71 P006157, P006164, P006202, P006305, P274471.

72 P006029, P006040, P006072, P006083, P006187, P006203, P006271, P006278, P006291.

73 P235786, P231784, P231786, P006187.

74 P006332, P006381 (ŠE i HI, na aversu su česti simboli GAR, SAL DAM E 2 i SAG pa se možda radi i o porcijama hrane za radnice).

75 P006061, ali na prednjoj strani pločice, u jednom stupcu teksta, zapisane su 4 različite radnice (SAL).

76 P006030.

77 Na jednoj je od njih uz ječam spomenut i proizvod zapisan simbolom HI.

78 P006029, P006157, P006278.

79 Dva dokumenta sa simbolom DAR (P006030, P006061) i jedan sa simbolom MUŠEN (P006040).

80 P006061.

81 Unosi na pločici jesu TUG MAR ZATU852 $\mid$ ŠE.NAM $_{2} \mid$ APIN (o III 1) i NAM 2 APIN MAR NA (r I 3).

82 P235786, Simbol PA zapravo je dvostruki simbol PAP pa se vjerojatno radi o različitim varijantama iste ideje koja stoji iza tih simbola. Na jednoj je uz simbol DAR.

83 P006271.

$84 \mathrm{P} 006202$.
} 
Na većini pločica iz Larse pronađen je simbol MAR (15 od 23 pločice), i to gotovo uvijek u kombinaciji s AN. ${ }^{85}$ Ta je kombinacija na devet pločica zapisana uz simbol PA, sedam puta na poziciji potpisnika računa. ${ }^{86}$ Većinom su zabilježeni poslovi s ječmom (šest pločica). ${ }^{87} \mathrm{U}$ jednom je dokumentu raspodjela porcija hrane, ${ }^{88} \mathrm{u}$ drugom raspodjela radnica za ŠIM. ${ }^{89}$ Simbol MAR u dvama je dokumentima zapisan u istom unosu sa simbolom APIN. Međutim, zbog poretka simbola veća je vjerojatnost da se u tom slučaju radi o poslovima oranja (APIN) koji se trebaju obaviti za AN MAR ili ih nadgleda službenik AN MAR. U dvama je dokumentima, uz kombinaciju AN MAR, zapisan i simbol ŠE pa prethodni zaključci vrijede i za njih.

U korpusu iz Djemdet Nasra simbol MAR pronađen je samo u četirima dokumentima i na jednoj leksičkoj listi (geografski toponimi).$^{90}$ Svima je u unosu sačuvan samo simbol MAR. Tri dokumenta bilježe poslove s ovcama i simbol $\mathrm{KU}_{3}{ }^{91}$. Jedna pločica, pretpostavlja se, bilježi dodjelu porcija hrane radnicima. ${ }^{92}$

Simbol MAR pojavljuje se još na dvama dokumentima iz Ukaira i na jednom iz Kiša. U Ukairu je, na obama dokumentima, u kontekstu ptica. ${ }^{93}$ Na jednoj pločici iz Kiša simbol MAR je u istom unosu sa simbolima HI, AN i BU. ${ }^{94}$

Među 30 pločica kojima se ne može utvrditi podrijetlo, 28 je administrativnih dokumenata na kojima je zapisan simbol MAR. Unutar te skupine najbrojniji su dokumenti o poslovima s ovcama ${ }^{95}$ i oni s KIŠ (po pet pločica) ${ }^{96} \mathrm{U}$ trima dokumentima zapisani su poslovi s ječmom, ${ }^{97}$ a po dva dokumenta bilježe raspodjelu

\footnotetext{
85 Samo je na jednoj bez tog simbola i unos je MAR NAM 2 (P005459).

86 Kombinacija AN MAR PA zapisana je na pločicama P005454, P005456, a na poziciji glavnih potpisnika računa na P005445, P005447, P005448, P005464, P005466, P005450, P005453. Samo AN MAR zabilježeno je na pet pločica i u svima je na poziciji potpisnika računa P005469, P005457, P005455, P005444, P005443. P005445, P005447, P005448, P005450, P005453, P005455, P005456, P005464. nom slučaju u istom je unosu sa simbolom MUŠEN i bilježi se, vjerojatno, raspodjel porcija ječma radnicama (P005403). U drugom (P005434) u unosu sa simbolom DAR vezano je uz poslove raspodjele trske (GI) i ptica (DAR). Oba su simbola stilizirani prikazi ptica (tijelo je ptice simbola DAR iscrtano), a to značenje imaju i u kasnijim sumerskim tekstovima (v. LMSZ, s. v. „mušen“ i s. v. „dar“).

P005291. Jasnije su vidljivi samo simboli MAR i BU, dok su simboli HI i AN diskutabilni. Teško je utvrditi koje su poslove bilježili jer je većina završnog obračuna dokumenta uništena. P325756, P006373, P382658, P006067, P325506. P252166, P252169, P252170, P252175, P252188.

P325506 (pločica ima samo dva unosa; u onom s MAR nalaze se i simboli ŠE i $U_{8}$ ), P006057, P005461.
} 
porcija hrane, ${ }^{98}$ poslove s ribama ${ }^{99} \mathrm{i}$ proizvodom $\mathrm{BARA}_{2}{ }^{100}$ Po jedna pločica bilježi još poslovanje s poljima, ${ }^{101}$ teladi (AMAR) ${ }^{102}$ i pticama (DAR) ${ }^{103} \mathrm{Za}$ osam dokumenata ne može se utvrditi koje su poslove bilježili. ${ }^{104}$ Od kombinacija sa simbolom MAR dominira unos AN MAR (šest puta), ${ }^{105}$ a još su jedanput zapisani AN MAR PA, ${ }^{106}$ MAR PAP, ${ }^{107}$ ŠE MAR ${ }^{108}$ i TAK $_{4}$ MAR. ${ }^{109}$

U navedenom korpusu simbol MAR zapisan je na dvjema leksičkim listama: $\mathrm{Lu}_{2} \mathrm{~A}$ i onoj Arhajske geografije. Na objema listama na kojima se također ovaj simbol pojavljuje u Uruku ovdje se javlja drugačija kombinacija. $\mathrm{Na} \mathrm{Lu}_{2} \mathrm{~A}$, na kojoj se u Uruku pojavljuje kombinacija MAR APIN, ovdje je unos |MARxGAR| GAL. Može se pretpostavljati da je tu zapisana vrsta poslova za koju je službenik MAR APIN bio primarno zadužen u nepoznatom središtu iz kojeg potječe navedena lista. Na listi ,geografski toponimi“ iz Uruka unos je ŠE MAR, dok se na pločici kojoj nije utvrđeno podrijetlo nalaze brojni unosi: EN DU MAR, TI MAR, X MAR, TUG $_{2}$ MAR, NAM ${ }_{2}$ GI MAR, GAR MAR, NAGA MAR, SAR MAR, KI MAR, X MAR, X DIN MAR, X UR MAR.

\section{Aktivnosti unutar kojih je simbol MAR zapisan (Tablica 1)}

Simbol MAR najčešće je zapisan u dokumentima o različitim poslovima $\mathrm{s}$ ovcama i kozama. Međutim, postoje znatne razlike između različitih korpusa. U onima iz grada Uruka, iz prve faze, dokumenti sa simbolom MAR najbrojniji su upravo u navedenoj kategoriji, ali ih u tekstovima iz sljedeće faze nema. U Umi se simbol MAR najčešće pojavljuje u dokumentima o tim poslovima, a česti su i u Djemdet Nasru gdje su većinom uz simbol $\mathrm{KU}_{3}$.

Sljedeća vrsta dokumenata, u kojima se najčešće spominje simbol MAR, bilježi poslove s ječmom. Zamjetno je da se i u tekstovima iz Uruka znatna količina te vrste dokumenata pojavljuje u korpusu Uruk IV., dok je među tekstovima iz faze Uruk III. samo jedan unutar kojeg je zapisan simbol MAR. Odnosi se na raspodjelu ječma za $\mathrm{KU}_{2}$ S̆IM, i to većim dijelom za porcije hrane $\left(\mathrm{GU}_{7}\right)$.

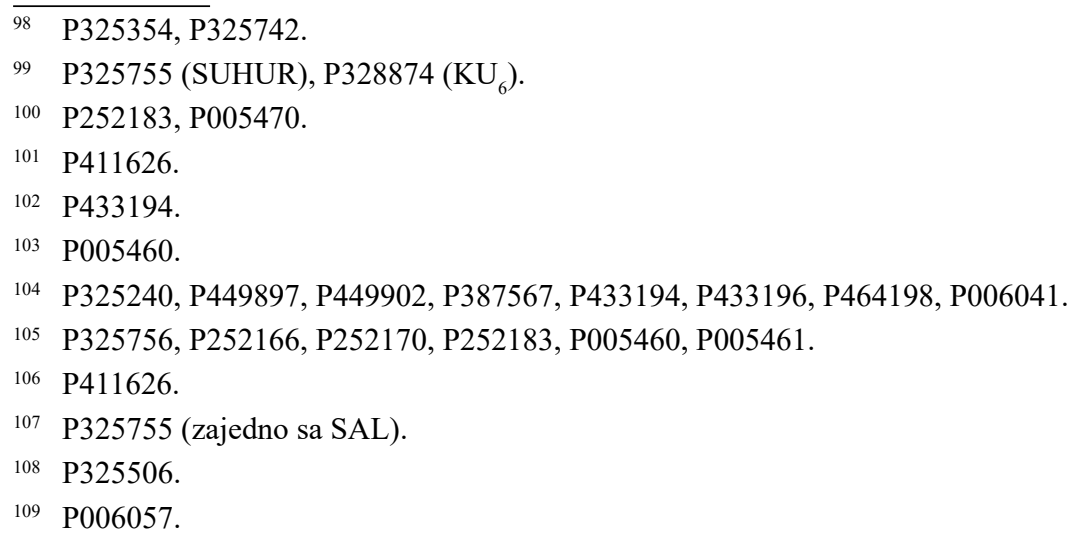


Nakon navedenih dokumenata, koji bilježe dvije temeljne grane proizvodnje tog vremena u južnoj Mezopotamiji, slijede oni kojima se dijele porcije hrane. Budući da uglavnom bilježe radnu snagu kojoj je hrana namijenjena, moglo bi ih se povezati sa sljedećom najzastupljenijom kategorijom, onoj o radnicama. To bi bila druga najzastupljenija kategorija dokumenata u kojima se pojavljuje simbol MAR. ${ }^{110}$ Najviše ih je pronađeno $u$ Uruku, $u$ arhivu druge faze, dok je samo jedan takav zapis iz one prethodne. Unutar svih ostalih korpusa samo po jedan dokument o raspodjeli hrane ${ }^{111}$ bilježi simbol MAR. Na tim je pločicama zapisan samostalno (Uma i Djemdet Nasr) ili u kombinaciji simbola kojima se opisuju neka lokacija ili vrsta poslova (Larsa - AN MAR, Ukair MAR MUŠEN ZATU 756). ${ }^{112}$

Dokumenti o radnicama, u kojima je zapisan simbol MAR, pronađeni su samo u korpusima iz Uruka (2 pločice iz prve i 2 iz druge faze), Ume (3 pločice) i Larse (1 pločica). ${ }^{113}$ Teško je nešto određeno reći za tekstove iz prve faze u korpusu iz Uruka. U onima iz druge faze radnicama se u jednom dokumentu daju porcije hrane $\mathrm{GU}_{7}{ }^{114}$ dok se u drugom dijele GAR i KAŠ raznim institucijama i službenicima. ${ }^{115} \mathrm{U}$ obama dokumentima MAR je dio titule. U Umi pronađeno je najviše dokumenata o radnicama, ali se samo za jedan može utvrditi da bilježi poslove s tkaninom. ${ }^{116}$

Simbol MAR često je zapisan i u dokumentima sa simbolom KIŠ.${ }^{117}$ U prvoj je fazi u pitanju samo jedan takav dokument nepoznatog podrijetla. $U$ drugoj fazi u

110 Samo se za četiri dokumenta, u kojima se bilježe poslovi s porcijama hrane, može reći da se odnose na radnice (SAL) i radno sposobne osobe (AL). Stoga bi zbroj dokumenata, koji bilježe bilo kakve poslove s radnom snagom, bio nešto manji od onih koji bilježe poslove o ovcama $\mathrm{i}$ kozama (22 pločice - 19\%).

111 Na tim se pločicama samo u Djemdet Nasru koristi simbol $\mathrm{GU}_{7}$, dok je u svim ostalim (Uma, Larsa i Ukair) zapisan simbol GAR.

112 Simbol ZATU 756 zapravo je šrafiran simbol A pa se može pretpostaviti da je označavao posebnu vrstu kanala ili poslova na kanalima. U dokumentu se taj simbol pojavio uz simbol za polja $\mathrm{GAN}_{2}$. I u ostalim su unosima zapisani simboli RAD (varijacija simbola A) i ZATU 757 (podvostručen simbol ZATU 756). Smatram da je na pločici zapis radova na riječnim kanalima (možda poslova oko navodnjavanja) pa bi se MUŠEN moglo odnositi i na simbol ZATU 756 - „kanal (na području) ptica“. MAR bi mogao karakterizirati vrstu poslova.

113 Obračun je SAL ŠAM ${ }_{2}$ AN MAR ŠIM, a na aversu je jedan unos MAR PAP SAL.

114 Na reversu broje se poslovi okarakterizirani simbolima $\mathrm{SI}_{4}$ i AZ.

115 Na velikom su broju unosa simboli SAL i TUR. Simbol TUR se na popisima djece pojavljuje zajedno sa simbolima za jednogodišnje, dvogodišnje ili trogodišnje dijete. Moguće je da je, općenito, oznaka za djecu još uvijek vezana uz majku. Revers je uništen pa se ne znaju dodatne informacije o poslovima.

116 Za druge dvije može se utvrditi da bilježe raspodjelu ŠE i HI te zapis radnica koje se dodjeljuju raznim institucijama ili za razne poslove (konačan je obračun DAR MAR PAP SU).

117 Simbol je prikaz neke životinje s dugim ušima, kojem se u kasnijim sumerskim tekstovima ne može utvrditi značenje, nego samo da je bio dijelom najranijeg zapisa imena boga Nergala (LMSZ: 361). 
korpusu iz Uruka zapisan je u dokumentima o poslovima s KIŠ samo jednom. U Umi zapisan je u četirima dokumentima, a u svima je KIŠ predmet transakcije. U korpusu iz Larse samo je u jednom dokumentu. Simbol MAR se na pločicama nepoznata podrijetla sveukupno pojavljuje na 6 pločica koje bilježe poslovanje s KIŠ.

Što se tiče ostalih poslova koji su zapisani sa simbolom MAR samo se još u dokumentima o govedima mogu utvrditi razlike između pojedinih korpusa. Već je prije zamijećeno da se goveda puno više spominju u tekstovima prve faze ${ }^{118}$ pa ne začuđuje da se među njima nalaze i oni na kojima je zapisan simbol MAR (dvije pločice). U korpusima iduće faze dokumenti o govedima, u kojima se nalazi i simbol MAR, pronađeni su samo u Umi (1 pločica) i još na jednoj pločici nepoznata podrijetla. Dokument iz Ume bilježi poslove sa simbolom KIŠs, ali je u završnom obračunu dodan i simbol AMAR (,tele“). U dokumentu nepoznata podrijetla, u kojem je također AMAR vjerojatno predmet računa, možda se bilježe poslovi sa simbolom KIŠ. ${ }^{119}$

\section{Najučestalije kombinacije u kojima je zapisan simbol MAR (Tablica 2)}

Od kombinacija u kojima je simbol MAR najčešće zapisan u administrativnim dokumentima najučestalija je AN MAR. Pronađena je unutar gotovo svih korpusa tekstova (osim onih iz Ukaira i Kiša). Ako se toj kategoriji pribroji i posebno izdvojena kombinacija AN MAR PA, ${ }^{120}$ onda je taj postotak još i veći. ${ }^{121}$ Relativno je česta i kombinacija PA/PAP MAR bez simbola AN. ${ }^{122}$

Kombinacija AN MAR zajedno sa simbolom PA dominantna je u Larsi i uvijek je vezana za poslove s ječmom. U četirima dokumentima u kojima se javlja samostalno uvijek je zapisana na poziciji konačnog obračuna. Za dva dokumenta iz Ume, u kojima je zapisana kombinacija AN MAR, ne može se ništa konkret-

\footnotetext{
118 V. ENGLUND 1995: 33.

119 Iako nije sačuvan unos sa simbolom KIŠ, uz AMAR zapisan je i simbol KUR. Sâm AMAR upisan je u simbol $\mathrm{DU}_{8}$ kao u dokumentu iz Ume. Simbol $\mathrm{DU}_{8}$ mogao bi biti stiliziran prikaz tora ili ,sabirnog mjesta“ za životinje. U cjelokupnom korpusu protoklinastih tekstova relativno se rijetko pojavljuje, uvijek u dokumentima o raspodjeli hrane $\left(\mathrm{GU}_{7}\right.$, najčešće $\mathrm{GUG}_{2}$ i GAR, ali i KAŠ i DUG), ovcama, AMAR i KIŠ. U njega su isključivo upisani simboli UDU ili AMAR. Inače se AMAR pojavljuje u 17,7\% dokumenata u kojima je simbol KIŠ predmet obračuna (18 od 102 dokumenta). Možda označava mlado bilo koje vrste krupne stoke.

120 Izdvojena je zbog dominacije u korpusu iz Larse, iako se javlja i jednom u Uruku te na pločicama nepoznatog podrijetla.

121 Četvrtina korpusa (25\%) pločica unutar kojih je zapisan simbol MAR.

122 Simbol PA potpuno je stiliziran (kao dva štapa s dodatnom „ručicom“ = dva simbola PAP). Kasnije je sumersko značenje 'grana' (LMSZ: 546). Često je dio raznih titula pa se ne može ništa konkretnije zaključiti, osim da je to možda oznaka autoriteta pojedinih administratora i/ ili nadglednika.
} 
nije reći. Međutim, na pločici sa zapisom PAP MAR obračunava se KIŠ, dok je na drugoj DAR MAR PAP SU konačan opis transakcija. Simbol MAR se u navedenim kombinacijama pojavljuje i u korpusu iz grada Uruka. Najbrojniji su na pločicama iz prve faze. ${ }^{123}$ Kombinacija AN MAR u toj se skupini pojavljuje u dvama dokumentima koji bilježe ŠELU, $\mathrm{KU}_{3}$, NAGAR i TUN ${ }_{3}$ poslove te još jednom o porcijama hrane. Unutar uručkog korpusa iz druge faze samo su jednom zapisane kombinacije AN MAR i AN MAR PA. Na čak šest pločica nepoznatog podrijetla zapisana je kombinacija AN MAR. Jednom potpisuje poslove s ovcama, dva puta je na pločicama o poslovima s KIŠ, jednom u dokumentu o BARA, jednom se odnosi na poslove sa svinjama i pticama DAR i još jednom na ječam $i$ $\mathrm{UR}_{5}$. Na jednoj iz te skupine pločica zapisano je AN MAR PA, ${ }^{124}$ a na drugoj MAR PAP SAL. ${ }^{125}$ Najčešća kombinacija AN MAR, zajedno u raznim varijacijama sa simbolima PA i PAP, nije zapisana niti na jednoj leksičkoj listi. One, pak, bilježe tri kombinacije sa simbolom MAR, među kojima se, unutar administrativnih dokumenata, najčešće pojavljuje MAR ŠE, uglavnom dominantna u najranijim tekstovima. ${ }^{126}$

Za kombinaciju zapisanu u $\mathrm{LU}_{2}$ A listi (APIN MAR) jedino možemo sa sigurnošću reći da bilježi titulu. Zapisana je samo na administrativnim pločicama iz Uruka $^{127}$ i na jednoj iz Ume. Dokumenti druge faze Uruka, u kojima je zapisano MAR APIN, svi označavaju porcije hrane. U jednom se $\mathrm{GU}_{7}$ dodjeljuje većinom službeniku SANGA od $\mathrm{KU}_{2}$ ŠIM (pivovara?). ${ }^{128}$ Drugi dokument bilježi raspodjelu $\mathrm{GU}_{7}$, ali i GI GAN 2 (polja trske?) za $\breve{S} E \mathrm{KU}_{2}$ S̆IM (ječam za pivovaru?). Moguće je i da se u obama slučajevima označava izdavanje piva iz pivovare kao porcije hrane drugim sektorima proizvodnje (pivo kao dio nadnice radnicima). I u trećem je dokumentu MAR APIN jedan od unosa na reversu, gdje su gotovo svi drugi unosi također titule ili institucije. ${ }^{129} \mathrm{U}$ Umi je simbol MAR zapisan uz APIN samo u jednom dokumentu o tkanini, ali sudeći prema poziciji zapisanih simbola i njihovu karakteru, nije vjerojatno da se radi o službeniku s titulom MAR

${ }_{123}$ Simbol MAR je tri puta zapisan uz AN, dva puta uz PA i jednom uz PAP (MARxŠE). Uz kombinaciju MAR PA jednom je zapisan simbol UDU, a na drugoj je zapisan samo simbol ZATU 699.

124 Bilježe se polja za/od BULUG .

125 Vjerojatno se bilježe porcije hrane.

126 Jednom je još zapisana unutar dokumenata iz druge faze iz Uruka i jednom u onima nepoznatog podrijetla.

127 Na jednoj iz prve i tri iz druge faze.

128 U glavnom unosu aversa i njegovu ,podunosu“ zapisane su potvrđene titule pa bi se možda moglo pretpostaviti da je to primopredaja jednoga drugome službeniku (iz jednog sektora proizvodnje drugome).

129 Poslovi koji se bilježe jesu $\mathrm{GU}_{7}$, a njihova je pobliža karakterizacija $\mathrm{SI}_{4}$ AZ GAL SANGA SANGA i $\mid$ GIŠ.TE|. 
APIN, već prije o $\mathrm{NAM}_{2}$ APIN i MAR DAR kombinaciji koja se u tom korpusu pojavljuje u još dvama dokumentima.

Najučestalija je kombinacija u Umi I MAR. Tri od četiriju pločica na kojima je zapisana dokumenti su o poslovima s ovcama. ${ }^{130}$ Simbol I sastoji se od 5 ureza i teško je pretpostaviti što je u ono vrijeme predstavljao. ${ }^{131}$ Sljedeća kombinacija simbola koja se učestalo bilježila u Umi jest DAR MAR, ikonografski jasnija od prethodne. ${ }^{132}$ Simbol MAR se i u tekstovima iz Ukaira također pojavljuje jedino u kombinaciji sa simbolom za ptice, i to jednom s MUŠEN i jednom s DAR.

\section{Razmatranja nakon analize simbola MAR}

Nakon pregleda i analize protoklinastih tekstova u kojima je zapisan simbol MAR odmah se uočava da je u najvećem korpusu (uručki iz druge faze) relativno malo dokumenata u kojima je zabilježen. ${ }^{133}$ Slično se vidi i kada se u obzir uzme vrsta poslova unutar kojih ima neku ulogu. Dokumenata o ovcama i ječmu, koji su brojni u korpusu prve faze, u sljedećoj gotovo uopće nema; sačuvan je samo po jedan. Mogući je razlog taj da su, nakon inicijalne faze pisma potvrđene sa sigurnošću samo u gradu Uruku (što bi značilo da se i cjelokupna dokumentacija skladištila u tom arhivu), u sljedećoj fazi postojala i druga administrativna središta u kojima su se obrađivali i spremali dokumenti za poslove uglavnom pod upravom tih ogranaka. Promjenu između prve (Uruk IV.) i druge (Uruk III.) faze pisma prati i promjena u gradnji glavnog središta administracije toga grada, Eane. $\mathrm{Na}$ kraju sloja IV. cijelo je područje nivelirano te se u Eani gradi potpuno novi kompleks građevina. ${ }^{134}$ Veliki broj pločica s protoklinastim pismom i otiscima pečata pronađen je u takozvanom „Velikom dvorištu“. I taj je kompleks građevina na kraju te faze u potpunosti srušen, a arhitektura sljedećeg sloja III pokazuje znatno drugačiji plan. ${ }^{135}$

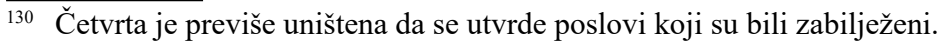

131 Simbol se inače jako rijetko pojavljuje u tekstovima iz uručkog razdoblja, samo na 31 pločici.

132 Simbol DAR spada u istu kategoriju simbola kao i KIŠ. Oba su varijacije simbola često zabilježenih životinja čije je značenje potvrđeno i u kasnijim, fonetski zapisanim tekstovima samo što imaju dodatno urezane linije na šiji ili drugdje po tijelu. To bi se moglo interpretirati na način da simboli s dodatnim urezima predstavljaju divlju vrstu koja tada nije bila prisutna u južnoj Mezopotamiji ili da su podrijetlom iz krajeva od kuda se dobavljaju divlje životinje.

133 U korpusu iz Uruka postotak dokumenata sa simbolom MAR najmanji je $(0,6 \%$ od 2.434 dokumenta, v. Tablicu 1). Najveći postotak utvrđen je u korpusu iz Larse (65\%), ali sačuvana su samo 23 dokumenta. Slijede Kiš (16,7\%, iako korpus čini samo 6 pločica), zatim Uma (5,1\% od 402 dokumenta), Ukair ( $5 \%$ od 42 pločice) te na kraju, prije Uruka, Djemdet Nasr $(1,7 \%$ od 239 dokumenta).

134 LEICK 2002: 37; ENGLUND 1994: 13-16; CHARVÁT 2002: 104.

135 CHARVÁT 2002: 104; FINKBEINER 1986: 46; SCHMANDT-BESSERAT 1988a: 10, 11
} 
Sudeći prema podacima iz analiziranih dokumenata jedno od središta koje je rukovodilo djelom proizvodnje bila je Uma, gdje se simbol MAR najviše pojavljuje u dokumentima o poslovima s ovcama i kozama, dok se, možda, u Djemdet Nasru obavljala kupovina/prodaja. ${ }^{136}$ Larsa je tada bio centar koji je rukovodio dijelom poslova uzgoja ječma.

Simbol MAR, vezan uz poslove s ovcama i kozama i ječmom, bio je relevantan samo za administraciju koja je izravno upravljala navedenim poslovima pa se u dokumentima središnje institucije u Uruku nije trebao spominjati. Drugim riječima, nije bio bitan kao oznaka kvalitete ili svrhe poslova, ali je nadležnim institucijama bio relevantan pri izvođenju navedenih poslova. ${ }^{137}$

U prilog toj interpretaciji ide i moguće značenje kombinacije koja se najčešće zapisivala kao AN MAR. Simbol AN ${ }^{138}$ najčešće se prevodi kao „božanstvo“pa se piše kao determinativ ispred imenâ svih božanstava, čime pobliže označava riječ koja slijedi. ${ }^{139}$ Postojao je drugi simbol, koji je najvjerojatnije označavao hram (simbol AB), ${ }^{140}$ ali je u tekstovima vjerojatno označavao stvarnu građevinu. ${ }^{141}$ Simbol MAR nikad se ne nalazi u istom unosu sa simbolom AB. Stoga se može pretpostaviti kako se smatralo da i stvar/područje/ideja, koji su stajali uz taj simbol, pripadaju božanstvu, ali nisu fizički bili u hramu. Navedeno možda potkrepljuje činjenica da je u dokumentima iz Larse AN MAR bez simbola PA uvijek zapisan na poziciji konačnog obračuna. To uglavnom nisu dokumenti o ječmu, inače dominantni u korpusu iz Larse. Najčešća je kombinacija u Larsi AN MAR PA, koja je uvijek zapisana u dokumentima o ječmu, pa bi se moglo pretpostaviti da je sa

136 Sudeći prema zapisu simbola KU3, u većini dokumenata o ovcama i kozama. U kasnijim sumerskim tekstovima $\mathrm{ku}_{3}$ prevodi se kao 'srebro' (LMSZ: 364). Ako se takvo značenje uzme i za protoklinasti simbol, koji izgleda kao iscrtani grumen neke tvari, dokumenti su možda evidentirali prodaju ili kupnju ovaca.

137 U slučaju Ume u obzir dolazi i mogućnost vrste poslova. Ovčarstvo je u većini ranih društava vezano uz transhumancu, to jest sezonsku seobu stada na područja gdje je u određenom razdoblju godine moguća ispaša.

138 Simbol AN stiliziran je prikaz najčešće osmerokrake zvijezde koji se u kasnijem fonetskom pismu koristi da bi se zapisao slog an, simbol sa značenjem 'nebo', kao ime sumerskog boga neba Ana, a vrlo često ima glasovnu vrijednost diğir te se prevodi riječju 'božanstvo'.

139 U protoklinastim tekstovima AN je jedan od najčešće zapisanih simbola (539 pločica), što ne začuđuje jer su gotovo sve pločice pronađene unutar hramova ili su povezane s nekom hramskom institucijom. Često je zapisan uz simbole za kravu, ovcu, polja, titule administratora pa se može spekulirati da se njime jednostavno označavalo da određene stvari, ljudi pripadaju ili služe božanstvu.

140 Zapisan je na 333 administrativne pločice.

141 Simbol izgleda kao stiliziran prikaz građevine na brežuljku, a hramovi su se podizali upravo na brežuljcima iznad močvarnog terena. Sudeći prema pronađenom arheološkom materijalu (protoklinaste pločice, brojno posuđe, ostaci zapečaćenih vrata i spremnika...), u hramovima se obavljalo osnovno štovanje boga, ali se i skladištio barem dio proizvoda, sastavljala se administrativna dokumentacija te se vjerojatno odonud dodjeljivalo sjeme za sjetvu. 
simbolom PA označavala titulu službenika zaduženog za neke poslove vezane uz ječam. Kombinacija AN MAR je onda možda označavala opis poslova koji nisu izravno vezani uz proizvodnju ječma. Najčešća kombinacija AN MAR, zajedno u raznim varijacijama sa simbolima PA i PAP, nije zapisana niti na jednoj leksičkoj listi pa se može pretpostaviti da nije bila dio službene središnje administrativne ideološke podjele grada Uruka. Ipak je zapisana u brojnim dokumentima, čak i na nekima iz Uruka, ${ }^{142}$ pa je zasigurno imala ulogu u administraciji. Moguće je da je službenik s titulom PA/PAP bio isključivo odgovoran za središta proizvodnje izvan grada Uruka, što bi se onda moglo povezati s kasnijim pisanjem titule „gradskog namjesnika“" PA TE SI (ensi ${ }_{2}$ ).

Uzevši u obzir prethodna razmatranja o simbolici i administrativnom značenju simbola AN (i AB kojeg nema), može se pretpostaviti da su poslovi/mjesto MAR bili izvan fizičke domene grada Uruka, ali se smatralo da pripadaju „božanskoj“ sferi na koju je Uruk polagao pravo i na tome ideološki temeljio svoju kontrolu. Stvarna mjesta koja su izravno baratala MAR domenom bila su, prema dosadašnjim saznanjima, u Larsi i Umi. U ostalim korpusima kombinacije s AN MAR najčešće se pronalaze u dokumentima koji bilježe poslove o porcijama hrane radnicima, poslove s KIŠ i s DAR, one s ovcama, ŠELU, $\mathrm{KU}_{3}, \mathrm{NAGAR}_{\text {i TUN }}$ te jednom s tkaninom i poljima.

Sljedeća najčešća kombinacija sa simbolom MAR jest ŠE MAR. Poslovi s ječmom gotovo su sigurno bili izravno pod kontrolom središnje uprave u Uruku. Za taj sektor gospodarstva (održavanje kanala, kontrola plavnih voda, organizacija različitih radnji kad su vode opadale...) bila je potrebna koordinacija velikog broja ljudi, zatim plansko skladištenje na vjerojatno različitim lokacijama te redistribucija za daljnju sjetvu ili hranu radnicima i životinjama. Larsa je zasigurno bila jedno takvo središte jer se u tom korpusu koji, istina, nije velik, uglavnom nalaze dokumenti o raznim poslovima oko ječma. Dosta ih je okarakterizirano simbolom APIN. Takvih je središta zasigurno trebalo biti puno više, ali do danas još nisu pronađena. ${ }^{143}$

U uručkom korpusu druge faze dominiraju dokumenti o raspodjeli hrane. Međutim, iz prethodne je faze samo jedan takav zapis. O razlozima se, nažalost,

$\overline{142}$ Pogotovo iz prve faze i tu je uglavnom službenik za raspodjelu hrane radnicima.

143 Unutar leksičkih listi koje popisuju gradove i unutar kojih su se uspjela identificirati neka od u kasnijem vremenu poznatih urbanih središta, puno je veći broj onih čiji se „naziv“ (kombinacija simbola) u protoklinastim tekstovima ne može povezati ni s jednim do sada istraženim lokalitetom. Uzevši u obzir ekohistorijski kontekst tog vremena (močvarni karakter), kao i intenzitet istraživanja te kvalitetu ranih istraživanja južne Mezopotamije, može se očekivati da se do sada nisu ubicirala manja administrativna središta iz tog vremena (o postojanju brojnih južnomezopotamskih uručkih lokaliteta v. ADAMS 1981: 65), posebno ako nisu prerasla u nezavisna urbana središta u 3. tisućljeću pr. Kr. Najrelevantnija studija o ekološkim karakteristikama južne Mezopotamije u 4. tisućljeću pr. Kr. i pregled etnografskih studija o životu tzv. Marsh Arabs jest POURNELLE I ALGAZE 2014. 
može samo nagađati. Moguće je da se u početnim stadijima administracije, koja se koristila tim prvim pismom, raspodjela „nadnica“ bilježila i kontrolirala na drugačije načine, a možda i nije bila toliko kompleksna. Vezano uz navedenu konstataciju, jasno je da je u razdoblju Uruk III. velik broj dokumenata posvećen upravo tim poslovima. Uruk je, naime, bio središte u kojem su se utvrđivali dobit i daljnja raspodjela sredstava za iduću sezonu proizvodnje, što je podrazumijevalo da su se ondje određivale količina i vrsta namirnica namijenjenih radnicima svih dislociranih institucija. To je koji put naznačeno u dokumentu. Pojedinačni unosi unutar pojedinih korpusa izvan Uruka označavali su internu raspodjelu sredstava. U uručkom korpusu druge faze simbol MAR se u zapisima o porcijama hrane uglavnom pojavljuje samo kao dio titule (APIN MAR). Unutar svih ostalih korpusa samo je po jedan dokument o raspodjeli hrane u kojem je zapisan simbol MAR, i to samostalno (Uma i Djemdet Nasr) ili u kombinaciji simbola kojima se opisuju lokacija ili vrsta poslova (Larsa - AN MAR, Ukair MAR MUŠEN ZATU 756).

Neobično je da nema niti jednog dijela leksičke liste iz Ume s unosom simbola MAR. Tom korpusu, naime, pripadaju 22 pločice s leksičkim listama, među kojima su najbrojnije upravo one na kojima se MAR javlja najviše puta u Uruku $\left(\mathrm{Lu}_{2} \mathrm{~A}-11\right.$ pločica; „Arhajski metal“- 2 pločice). Za posljednju je listu donekle razumljivo što nema simbola MAR jer su obje pločice izrazito fragmentarno sačuvane. Međutim, od pločica s $\mathrm{LU}_{2}$ A listom njih pet je u potpunosti očuvano te je jasno da se u Umi koristila lista koja ima samo prve unose. ${ }^{144} \mathrm{U}$ Umi pronađeno je najviše administrativnih dokumenata sa simbolom MAR i očiti je zaključak da je titula MAR APIN postojala samo unutar središnje administracije grada Uruka (možda službenik zadužen samo za poslove s MAR) te nije imala nikakvu ulogu u administraciji grada Ume.

\section{Prijedlog značenja simbola MAR u protoklinastim tekstovima}

Analiza protoklinastih tekstova pokazala je da je simbol MAR predstavljao stvar ili ideju koje su bile bitne u drugoj fazi za one dijelove gospodarstva organizirane i nadgledane u institucijama smještenim u bližoj (Uma i Larsa) i daljnjoj (Djemdet Nasr, Kiš, Ukair) okolici grada Uruka. U Umi povezan je s ovčarstvom, u Larsi s poslovima s ječmom, a u Djemdet Nasru s prodajom ili kupnjom u sklopu ovčarske djelatnosti. U korpusu iz Uruka utvrđen je i najniži postotak dokumenata sa simbolom MAR. Ako uzmemo u obzir takvu interpretaciju, onda bi se ideja/ stvar koja stoji iza simbola MAR odnosila na dio poslova koji nisu bili izravno vezani uz „središnju upravu“ u Uruku. ${ }^{145}$

$\overline{144}$ Prva 42 unosa od njih 125. MAR APIN nalazi se na 74. mjestu službene uručke liste.

145 U gradu Uruku upravljalo se različitim djelatnostima koje bi i inače „glavni grad“ kontrolirao: usklađivanje proizvodnje ovisno o potrebama glavne institucije, raspodjela sredstava i radnika te utvrđivanje dobitka (viškovi i gubici). 
Uz to što je pronađen najmanji postotak dokumenata sa simbolom MAR, uglavnom je zapisan u dokumentima o raspodjeli porcija hrane bilježila raspodjela porcija hrane radnicima. Gotovo isključivo je dio titule (samo jednom zapisano je MAR ŠE). Najučestalija titula koja se u tom korpusu pojavljuje jest APIN MAR, zapisana samo $\mathrm{u} \mathrm{Lu}$ listi. Ondje se omjer administrativnih i leksičkih tekstova, u kojima je zapisan simbol MAR, ne podudara s općom slikom postotaka pronađenih vrsta tekstova. ${ }^{16}$ Neobično je da u korpusu iz Ume nema niti jednog dijela leksičke liste s unosom simbola MAR, s obzirom na to da mu pripadaju 22 pločice s leksičkim listama, među kojima su najbrojnije upravo one na kojima se MAR pojavljuje najviše puta u Uruku - $\mathrm{Lu}_{2}$ A (11 pločica) i „Arhajski metal“ (2 pločice). Iz toga slijedi da je taj službenik bio sastavni dio administracije grada Uruka koji je bio zadužen za raspodjelu porcija hrane radnicima. ${ }^{147}$

Uzevši u obzir ikonografiju simbola (Slika 1) kojem je osnovni dio simbol GA (,skladište, kontejner"?), u kojem se u tekstovima često nalaze upisani razni proizvodi ili simboli institucija kojima je vjerojatno pripadao, u simbol MAR samo su tri puta upisani simboli (LAGAB.ŠE $E_{3}$ S ŠE te jednom nepoznati simbol). Jedina je razlika između dvaju simbola dodatni urez pri simbolu MAR. Imajući na umu pretpostavljenu logiku stvaranja simbola protoklinastog pisma (stilizirani prikaz stvari/mjesta ili načina na koji se radnja odvijala), simbol MAR mogao bi biti dijelom obiju kategorija (stvarni predmet i radnja koja se njime izvodi). Simbol se relativno rijetko zapisivao pa, ako se uzme u obzir krajolik u kojemu su se bilježeni poslovi odvijali, gdje je osnovno prijevozno sredstvo bio čamac ili brod, ${ }^{148}$ moglo bi se pretpostaviti da je uglavnom podrazumijevao sredstvo prijevoza i zbog toga se nije posebno naglašavao. Međutim, u određenim dijelovima sezone i za potrebe određenih djelatnosti trebala su se koristiti i kola tijekom niskog vodostaja i za dovođenje sredstava do kopnom dostupnih područja. Kasnija sumerska značenja simbola MAR jesu 'kola' i 'nalet', za koja smatram da su vrijedila i u ovim prvim tekstovima (stvar - 'kola' i radnja - 'prijevoz kolima').

Riječi označene simbolom MAR često se pojavljuju u kontekstu poslova sa simbolom KIŠ. ${ }^{149}$ U 12 dokumenata sa simbolom MAR simbol KIŠ označava

$\overline{146}$ U Uruku pronađena su 2.434 administrativna dokumenta, što je $78 \%$ ukupnog broja pronađenih pločica, dok je leksičkih listi 674 (22\%).

147 To podupire i jedini unos simbola MAR na Lu2 listi, kojoj se ne može utvrditi podrijetlo. Unos je MARxGAR GAL.

148 Simbol $\mathrm{MA}_{2}$ izrazito se rijetko ističe u tekstovima - samo u devet dokumenata, od kojih je jedan datiran u pretprotoklinasto doba (Uruk V.). Njih je šest iz prve faze pisma, a samo jedan iz druge te pripada korpusu iz Ume (dva su u tekstovima kojima se ne zna podrijetlo).

149 Simbol KIŠ u protoklinastom korpusu zabilježen je u ukupno 102 administrativna dokumenta. Samo je sedam dokumenata iz razdoblja Uruka IV. koji ga bilježe, a u svima označava predmet transakcije. U sljedećoj je fazi simbol zapisan na 97 pločica. Najviše ih je pronađeno u korpusu iz Ume (35 pločica). U tim je dokumentima, osim u četirima slučajevima, KIŠ predmet bilježenih transakcija. U korpusu iz Uruka zapisan je u 15 dokumenata kojima se ne može utvrditi karakter 


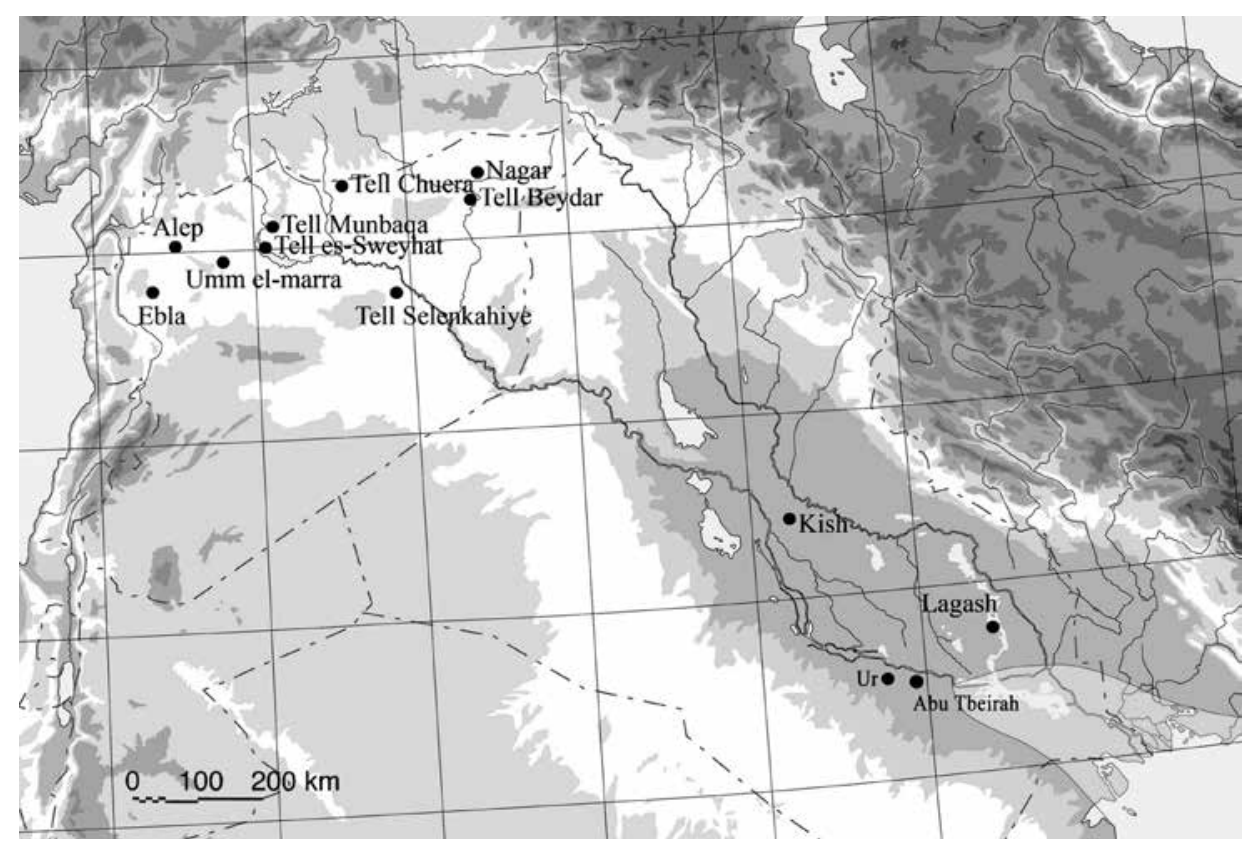

2. Karta lokaliteta na kojima se može potvrditi važnost mješanaca domaće i divlje vrste magaraca (preuzeto od DOLCE 2010; dodan je samo lokalitet Abu Tbeirah kod Ura)

glavni predmet obračuna. Za simbol KIŠ već je predloženo ${ }^{150}$ da predstavlja vrstu divljeg magarca (onager), što i sugerira ikonografija samog simbola. Pitanje je je li se radilo o divljoj vrsti ili mješavini domaćeg i divljeg magarca. Simbol KIŠ je u većini slučajeva varijacija simbola ANŠE (glava magarca koja ima dodatne ureze na šiji). U interpretacijama protoklinastih dokumenata obično se ističe da označava onagers, što je iranska sorta divljeg magarca (Equus hemionus onager). Dvije različite varijacije simbola (Slika 2) mogle bi uistinu označavati dvije različite vrste divljeg magarca (Equus hemionus ili azijski divlji magarac te Equus hemionus onager ili perzijski divlji magarac). Možda je varijanta koja se najčešće nalazi u protoklinastim tekstovima (doslovno simbol ANŠE s dodatnim urezima) označavala mješanca domaćeg i divljeg magarca, čija su prisutnost i poseban status potvrđeni posljednjih godina na lokalitetima u Siriji, južnoj i sjevernoj Mezopotamiji (Karta 2). ${ }^{151}$ Na temelju sirijskih pisanih izvora i arheološkog kon-

bilježenih transakcija. Može se samo utvrditi da se najčešće javlja sa simbolima BARA ${ }_{2}, \mathrm{TUG}_{2}$ i UDU/UDUNITA. U korpusu iz Djemdet Nasra četiri su dokumenta u kojima je zapisan simbol KIŠ, a u korpusu iz Larse samo jednom, i to kao jedan od unosa koji dodatno kategorizira radnice, čija se raspodjela bilježi. Među 41 pločicom nepoznata podrijetla samo na devet ne označava predmet transakcije.

150 MONACO 2018.

151 V. u ALHAIQUE ET AL. 2014; DOLCE 2010. 


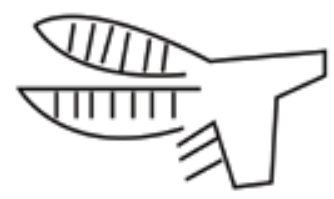

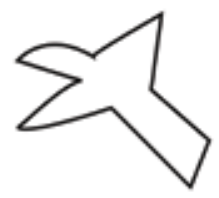

a)

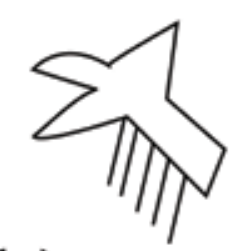

b)

2. Protoklinasti simboli KIŠ - b) (preuzeto s https://cdli.ucla.edu/dl/lineart/P002301_l. jpg i https://cdli.ucla.edu/dl/lineart/P005380_l.jpg, posjet 19.1.2020.) i ANŠE-a) (preuzeto s https://cdli.ucla.edu/dl/lineart/P000500_l.jpg, posjet 19.1.2020.)

teksta pronađenih životinjskih ostataka utvrđeno je i da su navedene životinje bile iznimno cijenjene u vladajućim krugovima te su bile među bogatim darovima koje su dvorovi izmjenjivali. Nema sigurnih potvrda prisutnosti takvih mješanaca u uručkoj ekonomiji, niti naznaka o njihovoj vrijednosti u društvu (nema niti prikaza životinjskih ostataka). Međutim, potvrđena je uručka prisutnost na području za koje se smatra da je u 3. tisućljeću pr. Kr. bilo središtem trgovine tim životinjama. Smatra se da je Tel Brak bio glavno trgovačko središte za te vrste mješanaca, a arheološkim je istraživanjima potvrđeno da je u Tel Braku, kao i u nekim drugim sirijskim središtima, krajem 4. tisućljeća pr. Kr. postojala jedna uručka enklava (kolonija). To je upravo prostor pretpostavljene amoritske pradomovine pa bi bilo izrazito nelogično da se uručki trgovci već u drugoj polovini 4. tisućljeća nisu susreli s autohtonom, moguće dijelom nomadskom, populacijom koju su današnji znanstvenici povezali s mezopotamskim i biblijskim Amoritima. ${ }^{152}$ To nikako nije potvrda da se MAR već u tom razdoblju odnosio isključivo na navedeni prostor, već je samo indikacija da se mogao, uz ostalo, odnositi i na nj.

Uzevši u obzir prethodna razmatranja smatram da je simbol MAR prvotno označavao stvar/ideju „kola/prijevoz kolima“. Sredinom 3. tisućljeća pr. Kr., kad se htjelo naznačiti određeno mjesto ili ljude koji su se okarakterizirali tim pojmom, dodan je simbol TU. Možda je bio samo fonetski dodatak, no ne smije se zanemariti pretpostavka da je, zajedno sa simbolom MAR, mogao označavati neku ideju. MAR.TU je mogao označavati skupni naziv za sva područja do kojih je trebalo doći kolima, a bila su od trgovačkog interesa južnomezopotamskim

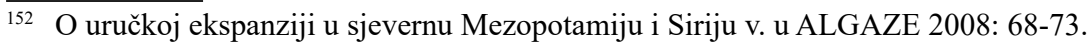


središtima. Mora se uzeti u obzir i mogućnost da se navedenim sklopom simbola grupno označavalo sve ljude koji su se kretali kolima kada je razina voda poplava počela opadati. Tada je i bilo moguće ući u južnu Mezopotamiju. U navedenom bismo slučaju izvorni MAR.TU trebali prevesti jednostavno kao 'migranti', bez specifikacije njihova odredišta ili etničke ili bilo kakve druge pripadnosti.

\section{Amoritski identiteti}

Pri analizi naziva ljudi i prostora u starim izvorima, uvijek bi se prilikom interpretacije trebalo uzeti u obzir tko je izdao relevantne dokumente i koja im je bila svrha u vremenu kada su napisani. Za određenu vlast pojedini prostori bili su nevažni, ali već su se sljedeći vladari možda borili za prevlast nad njima. Shodno tome je i slika pojedinih prostora i njihovih stanovnika različita u drugačijoj političkoj situaciji. Tako i jedan naziv za područje i ljude može tijekom stoljeća, kada se višestruko mijenjala politička situacija, doživjeti niz promjena. Značenje sumerograma MAR.TU također se tijekom stoljeća političkih promjena višestruko promijenilo. Od prvotnog područja u istočnoj Siriji, koje je bilo od trgovačkog interesa za elitu Sumera, postalo je oznaka za barbarske neprijatelje na granicama sjeveroistočne Mezopotamije, koji su ugrožavali kontrolu nad trgovačkim putovima južnomezopotamskog kraljevstva Treće urske dinastije. Najzad se uzdižu na jugu i sjeveru Mezopotamije Babilon i Ašur kao predvodnici novog doba mezopotamske povijesti.

Pismo je u Mezopotamiji nastalo zbog administrativne potrebe, a prvotno značenje protoklinastih simbola odnosi se na važne aktivnosti i područja od ekonomskog interesa za središta s kraja 4. tisućljeća pr. Kr. Prvotna oznaka za vrstu transporta te možda prostora od trgovačkog interesa, do kojeg se dolazilo kad bi vode poplava opadale, dobila je u vrijeme krize novo značenje. U prvoj polovini 3. tisućljeća pr. Kr. južnom Mezopotamijom više ne dominira jedno urbano središte, već ih je dvadesetak. Pismo je postalo fonetsko pa stari simboli dobivaju novo značenje. U tom kontekstu treba promatrati novi sumerogram MAR.TU. U pisanim izvorima tog doba on je samo indikator strane zemlje/ljudi. Imena tih ,prvih Amorita“ uglavnom nisu amoritska, a područje koje se označava tim sumerogramom vjerojatno je širi prostor sirijskoga gorja Djebel Bišr. Tijekom stoljeća promjene političke, a vjerojatno i društvene situacije $u$ južnoj Mezopotamiji, taj se naziv vezao za stanovništvo i prostor sjeveroistočne Mezopotamije. Promijenjeno je područje i osobe opisane kao MAR.TU sada većinom imaju amoritska imena. Također, MAR. TU postali su i ,necivilizirani barbari“. Ime koje se prvotno vezalo uz područja od trgovačkog interesa za južnomezopotamske gradove počelo se vezati za područja s kojima su se ti gradovi borili za prevlast nad važnim trgovačkim putovima. U tim se izvorima jasno može vidjeti propaganda vlasti koja preuzima ime MAR. TU i veže ga za drugi prostor, kao što mu daje i novi „barbarski“ karakter. Tim su se nazivom tada nazivali svi koji su napadali granice Treće urske dinastije, 
iako je dio njih već prisutan u sumerskom društvu. $U$ tom kontekstu vjerujem da bi se MAR.TU mogao prevesti kao migranti ('došljaci sa sjevera'). U vrijeme kada su MAR.TU postali vladari urbanih središta već se puno toga promijenilo i u navedenim sredinama, ali i u ideologijama stanovništva. Neki MAR.TU već su bili možda druga ili treća generacija koja je živjela u urbanim središtima južne Mezopotamije. Kada je zakazao prethodni upravljački aparat, onaj Treće urske dinastije, trebalo je samo da sposobni pojedinci preuzmu stvar u svoje ruke. MAR. TU je ponovno dobio novo značenje, ali je ovaj put to naziv kojim se ponose $\mathrm{i}$ ističu ga novi vladari starog Sumera. Oni preuzimaju staru sumersku kraljevsku tradiciju, ali u nju ugrađuju novi identitet „kraljeva koji su vladali iz šatora“. U rasuto je društvo došla nova vlast, ljudi iz klanskih veza koji su se udružili ili su možda tek stvorili klanove da učvrste saveze između pojedinih gradova. Starim su istokom tada zavladali „Amoriti“.

Danas smo svjedoci slične situacije. Često se govori o migrantima i „migrantskoj krizi“, a samo se rijetko u medijima izdvajaju pojedinci iz određenog područja i određenog statusa. Svi su za našu, ,zapadnjačku“ ideologiju jednostavno migranti (došljaci s Istoka). Možda za dvjestotinjak godina na „Zapadu“ postanu vladari.

Tablica 1 .

\begin{tabular}{|c|c|c|c|c|c|c|c|c|c|}
\hline \multirow{3}{*}{$\begin{array}{c}\begin{array}{c}\text { Vrsta } \\
\text { poslova }\end{array} \\
\text { Razdoblje } \\
\text { Lokalitet }\end{array}$} & \multicolumn{8}{|c|}{ Simbol MAR } & \multirow{3}{*}{ Ukupno } \\
\hline & Uruk IV & \multicolumn{7}{|c|}{ Uruk III } & \\
\hline & $\begin{array}{c}\text { Uruk, } \\
\text { nepoznato }\end{array}$ & Uruk & Uma & Larsa & $\begin{array}{l}\text { Djemdet } \\
\text { Nasr }\end{array}$ & Ukair & Kiš & $?$ & \\
\hline $\begin{array}{l}\text { ovce i } \\
\text { koze }\end{array}$ & 8 & 0 & 9 & 0 & $\begin{array}{c}3(2 \mathrm{uz} \\
\left.\mathrm{KU}_{3}\right)\end{array}$ & 0 & 0 & 5 & $2522 \%$ \\
\hline $\begin{array}{c}\text { ječam } \\
\text { (ک̌́E) }\end{array}$ & 6 & 1 & $\begin{array}{c}2 \text { (1 uz } \\
\text { HI, GAR, } \\
\text { i SAG) }\end{array}$ & 6 & 0 & 0 & 0 & 3 & $18 \quad 16 \%$ \\
\hline $\begin{array}{c}\text { porcije } \\
\text { hrane }\end{array}$ & 1 & 7 & 1 & 1 & 1 & 1 & 0 & 2 & $1412,5 \%$ \\
\hline KIŠ & $\begin{array}{l}1 \text { (nepo- } \\
\text { znato) }\end{array}$ & 1 & 4 & 0 & 0 & 0 & 0 & 6 & $1211 \%$ \\
\hline radnice & $\begin{array}{l}2(1 \mathrm{je} \\
\text { SAG) }\end{array}$ & 2 & 3 & 1 & 0 & 0 & 0 & 1 & $98 \%$ \\
\hline goveda & 3 & 0 & 1 & 0 & 0 & 0 & 0 & 1 & $54,5 \%$ \\
\hline $\begin{array}{c}\text { priprema } \\
\text { polja }\end{array}$ & 0 & 3 & 0 & 0 & 0 & 0 & 0 & 0 & $33 \%$ \\
\hline riba & 0 & 0 & 0 & 0 & 0 & 0 & 0 & 2 & $22 \%$ \\
\hline tekstil & 0 & 0 & 1 & 0 & 0 & 0 & 0 & 0 & $11 \%$ \\
\hline $\begin{array}{l}\text { \% unutar } \\
\text { korpusa }\end{array}$ & $1,3 \%$ & $0,6 \%$ & $5,1 \%$ & $65 \%$ & $1,7 \%$ & $5 \%$ & $16,7 \%$ & $2,8 \%$ & $1,7 \%$ \\
\hline
\end{tabular}




\section{Tablica 2.}

\begin{tabular}{|c|c|c|c|c|c|c|c|c|}
\hline \multicolumn{8}{|c|}{ Najučestalije kombinacije sa simbolom MAR u administrativnim dokumentima } & \multirow{3}{*}{ Ukupno } \\
\hline Razdoblje & Uruk IV & \multicolumn{6}{|c|}{ Uruk III } & \\
\hline Lokalitet & Uruk & Uruk & Uma & Larsa & Ukair & $?$ & $\begin{array}{c}\text { leksičke } \\
\text { liste }\end{array}$ & \\
\hline AN MAR & 3 & 1 & 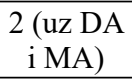 & 5 & 0 & 6 & & $1614,3 \%$ \\
\hline $\begin{array}{c}\text { AN } \\
\text { MAR PA } \\
\end{array}$ & 0 & 1 & 0 & 9 & 0 & 1 & & $11 \quad 10 \%$ \\
\hline MAR ŠE & 6 & 1 & 0 & 0 & & 1 & Toponimi & $87,1 \%$ \\
\hline $\begin{array}{c}\text { PA/PAP } \\
\text { MAR }\end{array}$ & $\begin{array}{c}2 \text { (PA) }+ \\
1 \text { (PAP) }\end{array}$ & 0 & 2 (PAP) & 1 (PAP) & 0 & $\begin{array}{c}1 \\
\text { (PAP) }\end{array}$ & & $76,3 \%$ \\
\hline $\begin{array}{l}\text { MAR } \\
\text { APIN }\end{array}$ & 1 & 3 & 0 & 0 & 0 & 0 & $\begin{array}{c}\mathrm{Lu}_{2} \mathrm{~A} \\
\text { lista }\end{array}$ & $54,5 \%$ \\
\hline $\begin{array}{c}\text { DAR/ } \\
\text { MUŠEN } \\
\text { MAR }\end{array}$ & 0 & & 3 & 0 & $\begin{array}{l}2 \text { (jednom } \\
\text { MUŠEN } \\
\text { i jednom } \\
\text { DAR) }\end{array}$ & 0 & & $54,5 \%$ \\
\hline I MAR & 0 & & 4 & 0 & 0 & & & $43,6 \%$ \\
\hline
\end{tabular}

Bibliografija

ADAMS, Robert McC. 1981. Heartland of cities. Chicago: University of Chicago Press.

ALBRIGHT, William F. 1922. Palestine in the earliest historic period. Journal of the Palestine Oriental Society 2: 110-138.

ALBRIGHT, William F. 1935. Presidential address. Palestine in the earliest historic period. Journal of the Palestine Oriental Society 15: 193-234.

ALBRIGHT, William F. 1965. Further light on the history of Middle-Bronze Byblos. Bulletin of the American Schools of Oriental Research 179: 38-43.

ALGAZE, Guillermo. 2008. Ancient Mesopotamia at the Dawn of Civilization: The Evolution of an Urban Landscape. Chicago: University of Chicago Press.

ALHAIQUE, Francesca, Licia ROMANO, Federica GABBIANELLI, Alessio VALENTINI, Franco D'AGOSTINO. 2015. A Sumerian equid burial from Abu Tbeirah (Southern Iraq). Convegno AIAZ, Associazione Italiana Archeozoologia. November $11^{\text {th }}-14^{\text {th }} 2015$. Lecce.

AMIRAN, Ruth 1960. The pottery of the Middle Bronze Age I in Palestine. Israel Exploration Journal 10: 204-225.

ARCHI, Alfonso. 2015. Ebla and Its ARCHIves. Texts, History, and Society [Series: Studies in Ancient Near Eastern Records (SANER) 7]. Boston: De Gruyter.

BAHRANI, Zainab 2006. Race and ethnicity in Mesopotamian antiquity. World Archaeology 38: 48-59. 
BAUER, Theo 1926. Die Ostkanaanaer: Eine philologisch-historische untersuchung über die wanderschicht der sogenannten ,Amoriter “ in Babylonien. Leipzig: Im verlag der Asia Major.

BEAULIEU, Paul-Alain. 2005. The God Amurru as Emblem of Ethnic and Cultural Identity. U ,Ethnicity in Ancient Mesopotamia“ Papers Read at the $48^{\text {th }}$ Rencontre Assyriologique Internationale, Leiden, July 1-4, 2002., ur. W. van Soldt, R. Kalvelagen, D. Katz [PIHANS 102; Nederlands Instituut voor her Nabije Oosten, 2005], 31-46.

BUCCELLATI, Giorgio 2008. The origin of the tribe and of ,industrial“ agropastoralism in SyroMesopotamia. U The Archaeology of Mobility: Old World and New World Nomadism, ur. Bernard H., W. Wendrich, 141-159. Los Angeles: Cotsen Institute of Archaeology.

BURKE, Aaron A., 2014a. Entanglement, the Amorite koine, and Amorite cultures in the Levant. ARAM Society for Syro-Mesopotamian Studies 26: 357-373.

BURKE, Aaron A., 2014b. Introduction to the Levant during the Middle Bronze Age. U The Oxford Handbook of the Archae of the Levant (c. 8000-332 BCE), ur. M. L. Steiner, A. E. Killebrew, 403-413. Oxford: Oxford University Press.

BURKE, Aaron A., 2017. Amorites, climate change and the negotiation of identity at the end of the third Millennium BC. U The Early/Middle Bronze Age Transition in the Ancient Near East Chronology, C14 and Climate Change, ur. F. Höflmayer, 261-307. Chicago: Chicago Oriental Institute.

CAMPBELL, Stuart 1999. Archaeological constructs and past reality on the upper Euphrates. U Archaeology of the Upper Syrian Euphrates, the Tishrin Dam Area: Proceedings of the International Symposium held at Barcelona, January $28^{\text {th }}-30^{\text {th }}, 1998$, ur. G. del Olmo Lete, J. L. Montero Fenollós, 573-583. Barcelona: Editorial Ausa.

CAMPBELL, Stuart, Alexandra FLETCHER. 2010. Questioning the Halaf-Ubaid transition. U Beyond the Ubaid: Transformation and Integration in the Late Prehistoric Societies of the Middle East, ur. R. A. Carter, G. Philip, 69-83. Chicago: University of Chicago Press.

CHARPIN, Dominique, Nele ZIEGLER. 2003. Mari et le Proche-Orient à l'époque amorrite. [Florilegium Marianum 5]. Paris: SEPOA.

CHARVÁT, Petr. 2002. Mesopotamia Before History. London - New York: Routledge.

de BOER, Rients 2014. Amorites in the Old Babylonian Period, $\mathrm{PhD}$ thesis, University of Leiden.

DEVER, William G. 1985. Relations between Syria-Palestine and Egypt in the „Hyksos“ Period. U Palestine in the Bronze and Iron Ages: Papers in Honour of Olga Tufnell, ur. J. N. Tubb, 69-87. London: The Institute of Archaeology.

DEVER, William G., Hubert D. LANCE. George E. WRIGHT. 1970. Gezer 1: Preliminary Report of the 1964-66 Seasons. Jeruzalem: Nelson Glueck School of Biblical Archaeology.

DOLCE, Rita. 2010. Equids as luxury gifts at the centre of interregional economic dynamics in the archaic urban cultures of the Ancient Near East. Syria 91: 55-75.

DURAND, Jean-Marie. 1998. Documents épistolaires du Palais de Mari. Tome II. [Littératures anciennes du Proche- Orient 17]. Paris: Les Éditions du Cerf. 
ENGLUND, Robert K. 1994. Archaic Administrative Texts from Uruk, The Early Campaigns. Archaische Texte aus Uruk V. Berlin: Gebr. Mann Verlag.

ENGLUND, Robert K. 1995. Late Uruk Period Cattle and Dairy Products: Evidence from Proto-Cuneiform Sources. Bulletin of Sumerian Agriculture 8/2: 33-48.

ENGLUND, Robert K. 2004. Proto-cuneiform account-books and journals. U Creating Economic Order: Record-keeping, Standardization and the Development of Accounting in the Ancient Near East, ur. Michael Hudson, Cornelia Wunsch, 23-46. Bethesda, Maryland, USA: CDL Press.

ENGLUND, Robert K., Jean-Pierre GRÉGOIRE. 1991. The Proto-Cuneiform Texts from Jemdet Nasr, Materialien zu den frühen Schriftzeugnissen des Vorderen Orients 1. Berlin: Gebr. Mann Verlag.

FINKBEINER, Uwe. 1986. Uruk-Warka. Evidence of the Gamdat Nasr Period. U Ğamdat Nasr: Period or Regional Style?, ur. U. Finkbeiner, W. Röllig, 33-56. Wiesbaden: Tübinger Atlas des Vorderen Orients Beiheft B62.

GELB, Ignace Jay. 1961. The Early History of the West Semitic Peoples. Journal of Cuneiform Studies 15: 27-47.

GLASSNER, Jean-Jacques. 2003. The Invention of Cuneiform. Writing in Sumer. Baltimore - London: The Johns Hopkins University Press.

GZELLA, Holger. 2014. Peoples and languages of the Levant during the Bronze and Iron Ages. U The Oxford Handbook of the Archaeology of the Levant (c. 8000-332 BCE), ur. M. L. Steiner, A. E. Killebrew, 24-34. Oxford: Oxford University Press.

HOMSHER, Robert S., Melissa S. CRADIC. 2017. The Amorite Problem: resolving an historical dilemma. Levant 49/3: 259-283.

HÖFLMAYER, Felix, Michael W. DEE, Hermann GENZ, Simone RIEHL. 2014. Radiocarbon evidence for the Early Bronze Age Levant: the site of Tell Fadous-Kfarabida (Lebanon) and the end of the Early Bronze III period. Radiocarbon 56/2: 529-542.

JOHNSON, Matthew 1999. Archaeological Theory: An Introduction. Oxford: Blackwell.

KAPLAN, Jacob. 1971. Mesopotamian elements in the Middle Bronze II culture of Palestine. Journal of Near Eastern Studies 30: 293-307.

KAPLAN, Jacob. 1975. Further aspects of Middle Bronze Age II fortifications in Palestine. Zeitschrift des Deutschen Palästina-Vereins 91: 1-17.

KARSGAARD, Philip. 2010. The Halaf-Ubaid transition: a transformation without a center?. U Beyond the Ubaid: Transformation and Integration in the Late Prehistoric Societies of the Middle East, ur. R. A. Carter, G. Philip, 51-67. Chicago: University of Chicago Press.

KENYON, Kathleen M. 1957. Digging up Jericho. London: Benn.

KENYON, Kathleen M. 1966. Amorites and Canaanites [The Schweich Lectures of the British Academy, 1963]. Jeruzalem: Israel Exploration Society.

LEICK, Gwendolyn. 2002. Mesopotamia. The Invention of the City. London: Penguin Books.

LIVERANI, Mario. 1992. The Amorites. U Mari in Retrospect: Fifty Years of Mari and Mari Studies, ur. G. D. Young, 100-133. Winona Lake: Eisenbrauns. 
LÖNNQVIST, Minna. 2009. Jebel Bishri in Syria and the Role of Nomadism in the End of the Early Bronze Age. U The Levant in Transition: Proceedings of a Conference held at the British Museum on 20-21 April 2004, ur. P. J. PARR, 49-55. Leeds: Maney.

LÖNNQVIST, Minna. 2010. How to control nomads? A case study associated with Jebel Bishri in central Syria: West Semitic nomads in relation to the urban world. U City administration in the ancient Near East. Proceedings of the $53^{e}$ Rencontre Assyriologique Internationale volume 2, ur. L. Kogan, N. Koslova, S. Loesov, S. Tischenko, 115-139. Winona Lake (IN): Eisenbrauns.

LÖNNQVIST, Minna, Markus TÖRMÄ. 2004. Different Implications of a Spatial Boundary, Jebel Bishri between the Desert and the Sown in Syria. U The ISPRS XX ${ }^{\text {th }}$ Congress Proceedings [The ISPRS International ARCHIves of the Photogrammetry, Remote Sensing and Spatial Information Sciences, Vol. XXXV. Part B], ur. M. Orhan Altan, 897-902. Istanbul.

MARCHESI, Gianni. 2006. LUMMA in the onomasticon and literature of ancient Mesopotamia. Padova: Sargon.

MICHALOWSKI, Piotr. 2011. The Correspondence of the Kings of Ur. An Epistolary History of an Ancient Mesopotamian Kingdom. Winona Lake: Eisenbrauns.

MONACO, Salvatore. 2018. Archaic Bullae and Tablets in the Cornell University Collections. Bethesda, Maryland: CDL Press.

NISSEN, Hans J., Peter DAMEROW, Robert ENGLUND. 1993. Archaic bookkeeping: early writing and techinques of economic administration in the ancient Near East. Chicago: University of Chicago Press.

PARR, P. 1968. The origin of the rampart fortification of the Middle Bronze Age Palestine and Syria. Zeitschrift des Deutschen Palästina-Vereins 84: 18-45.

PHILIP, G. 2011. The later prehistory of the southern Levant: issues of practice and context. U Culture, Chronology and the Chalcolithic:Transition in the Late Prehistory of the Southern Levant, ur. J. Lovell, Y. Rowan, 192-209. Oxford: Oxbow.

POURNELLE, Jennifer, Guillermo ALGAZE. 2014. Travels in Edin: Deltaic Resilience and Early Urbanism in Greater Mesopotamia. U Preludes to Urbanism: The Late Chalcolithic of Mesopotamia in Honour of Joan Oates, ur. Augusta McMahon, Harriet Crawford, 7-34. Cambridge: McDonald Institute for Archaeological Research.

RISTVET, Lauren. 2012. Resettling Apum: tribalism and tribal states in the Tell Leilan region, Syria. U Looking North: The Socioeconomic Dynamics of Northern Mesopotamian and Anatolian Regions during the Late Third and Early Second Millennium $B C$, 37-50. Wiesbaden: Harrassowitz.

SCHMANDT-BESSERAT, Denise. 1988. Tokens at Uruk. Baghdader Mitteilungen 19: 1-176.

UEHLINGER, Christoph. 1999. The „Canaanites“ and other ,pre-Israelite“ peoples in story and history (Part I). Freiburger Zeitschrift für Philosophie und Theologie 46: 546-578.

UEHLINGER, Christoph. 2000. The „Canaanites“ and other „pre-Israelite“ peoples in story and history (Part II). Freiburger Zeitschrift für Philosophie und Theologie 47: 173-198. 
WEISS, Harvey 2017. Seventeen Kings Who Lived in Tents. U The Early/Middle Bronze Age Transition in the Ancient Near East Chronology, C14 and Climate Change, ur. F. Höflmayer, 131-162. Chicago: Chicago Oriental Institute.

WHITING, Robert M. 1995. Amorite tribes and nations of second-Millennium Asia. U Civilizations of Ancient Near East, ur. J. M. Sasson, 1231-1242. New York: Scribner.

WILCKE, Claus. 1969. Zur Geschichte der Amurriter in der Ur-III-Zeit. Die Welt des Orients 5: 1-31.

\section{Kratice}

CDLI - The Cuneiform Digital Library Initiative, zajednički projekt University of California, Los Angeles, University of Oxford i Max Planck Institute for the History of Science, Berlin. https://cdli.ucla.edu/ (posjet 15. 11. 2019)

ETCSL - The Electronic Text Corpus of Sumerian Literature, Oriental Institute, University of Oxford. http://etcsl.orinst.ox.ac.uk/ (posjet 15. 11. 2019)

LMSZ - Leipzig-Müncher Sumerischer Zettelkasten (verzija 26. 9. 2006). https://www. assyriologie.uni-muenchen.de/forschung/forschungsprojekte/sumglossar/zettelkasten2006_09.pdf

Pxxxx - oznaka pločica u CDLI

\section{Popis ilustracija}

1. Protoklinasti simboli MAR - b) i GA - a) (preuzeto s: https://cdli.ucla.edu/tools/SignLists/protocuneiform/archsigns.html (posjet 15. 11. 2019))

2. Protoklinasti simboli KIŠ - b) i ANŠE - a) (preuzeto s: https://cdli.ucla.edu/tools/ SignLists/protocuneiform/archsigns.html (posjet 15. 11. 2019))

\section{Popis karata}

1. Karta južne Mezopotamije s lokalitetima uručkog razdoblja. Crvenim točkama označeni su lokaliteti na kojima su pronađene protoklinaste pločice.

2. Karta lokaliteta na kojima se može potvrditi važnost mješanaca domaće i divlje vrste magaraca (preuzeto od DOLCE 2010; dodan je samo lokalitet Abu Tbeirah kod Ura) 


\section{Amorite Identity: Symbol MAR in Protocuneiform Sources}

The starting point of this paper is the problem of identity, origin and migration of the Amorites. The earliest attestation of "Amorites" is Sumerian compound MAR.TU, which first appeared in the texts dating to about $2500 \mathrm{BC}$. This article concentrates on this Sumerian combination for which we still do not know how to pronounce it nor what it originally meant. I analyzed a corpus of protocuneiform texts and tried to identify within it the meaning of the symbol MAR. After examining 138 tablets (from Uruk, Umma, Larsa, Jemdet Nasr, Kish and Uqair) on which the MAR symbol (112 administrative and 26 lexical) was written, I concluded that the MAR symbol represented a thing or an idea that was in Uruk III phase important for the parts of the economy organized and supervised by the institutions located in the centers in vicinity (Uma, Larsa, Ukair) or more remote areas (Jemdet Nasr, Kish) of Uruk. In the Umma it was associated with sheep, in Larsa with barley and in Jemdet Nasri with the sale (or purchase) within the sheep industry. If we consider such an interpretation, then the symbol MAR, idea or thing behind this symbol, was part of the activities that were not directly related to the "central administration" in the city of Uruk. The MAR symbol is essentially a $\mathrm{GA}_{2}$ symbol ("storage, container"?) with an additional notch. Since the symbol is relatively rarely written, we should take into account the landscape in which recorded operations took place, where the primary means of transport was a boat or a ship. However, in certain season and for the needs of certain activities, wagons were also used (during low waters). One of the more common contexts in which the MAR symbol is written is that of operations with the KIŠ symbol. It was already suggested that it represent a wild donkey species as suggested by the iconography of the symbol itself. Two different variations of the symbols could indicate two different types of wild donkey and the variant most commonly found in protocuneiform texts may indicate a mix of domestic and wild donkey whose presence and exclusive status has been confirmed in recent years at sites in Syria, southern and northern Mesopotamia. There are no confirmations for the presence of such animals in the Uruk economy or any indication about their value in society. However, presence of the Uruk culture in the area thought to be a center of trade with wild donkeys in the $3^{\text {rd }}$ millennium $\mathrm{BC}$ was confirmed some time ago. That is also the area of the supposed Amorite homeland, so the tradesmen of Uruk had to meet the indigenous people that scholars associate with the Amorites. Considering the results of all this analyzes, I believe that the backbone of the original meaning of MAR was the thing/idea "wagon/wagon transport", what is also one of the later Sumerian meanings of the symbol MAR ("wagon", "rush") To this concept in the mid- $3^{\text {rd }}$ millennium BC symbol TU was added, for designation of a particular place or people. The TU symbol may have been just a phonetic supplement. MAR.TU could designate a collective name for all areas 
(which were of commercial interest) that had to be reached by wagons, but it could also denote all people who travel on wagons when flood water began to decline (when it was possible to enter southern Mesopotamia). In that case, the original MAR.TU should be translated simply as "migrants" without a specific specification about their homeland or ethnicity or any other affiliation.

Keywords: MAR.TU, Syria, Mesopotamia, protocuneiform texts.

Ključne riječi: MAR.TU, Sirija, Mezopotamija, protoklinasti tekstovi.

Jasmina Osterman Filozofski fakultet Sveučilišta u Zagrebu Ivana Lučića 3 HR-10000 Zagreb josterma@ffzg.hr 


\section{FILOZOFSKI FAKULTET SVEUČILIŠTA U ZAGREBU \\ ZAVOD ZA HRVATSKU POVIJEST \\ INSTITUTE OF CROATIAN HISTORY \\ INSTITUT FÜR KROATISCHE GESCHICHTE}

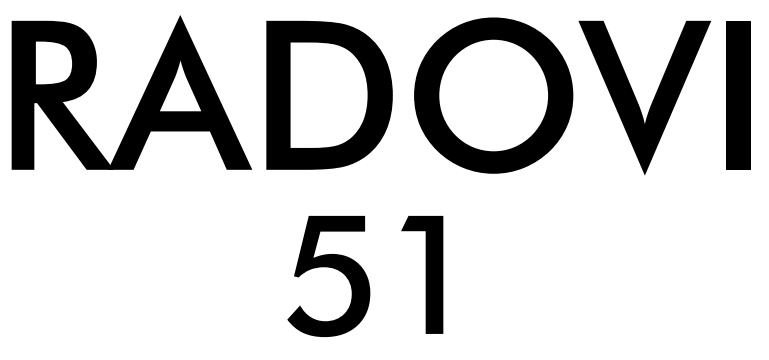

BROJ 1

ZAVOD ZA HRVATSKU POVIJEST

FILOZOFSKOGA FAKULTETA SVEUČILIŠTA U ZAGREBU

\section{FF press}

ZAGREB 2019. 


\section{Poseban broj}

Između Europe i Bliskog istoka: migracije i njihove posljedice na području Jugoistočne Europe $i$

Anadolije u transimperijalnom $i$ interkulturalnom kontekstu

\section{Special issue}

Between Europe and Middle East: Migrations and Their Consequences in Southeast Europe and Anatolia in Transimperial and Intercultural Context 


\title{
RADOVI ZAVODA ZA HRVATSKU POVIJEST FILOZOFSKOGA FAKULTETA SVEUČILIŠTA U ZAGREBU
}

\author{
Knjiga 51, broj 1
}

\author{
Izdavač / Publisher \\ Zavod za hrvatsku povijest \\ Filozofskoga fakulteta Sveučilišta u Zagrebu \\ FF-press \\ Za izdavača / For Publisher \\ Vesna Vlahović Štetić \\ Glavni urednik / Editor-in-Chief \\ Inga Vilogorac Brčić \\ Gostujući urednik / Guest Editor \\ Vjeran Kursar \\ Uredništvo / Editorial Board
}

Jasmina Osterman (stara povijest/ancient history), Trpimir Vedriš (srednji vijek/medieval

history), Hrvoje Petrić (rani novi vijek/early modern history), Željko Holjevac (moderna povijest/

modern history), Tvrtko Jakovina (suvremena povijest/contemporary history), Silvija Pisk

(mikrohistorija i zavičajna povijest/microhistory and local history),

Zrinka Blažević (teorija i metodologija povijesti/theory and methodology of history)

Međunarodno uredničko vijeće / International Editorial Council

Denis Alimov (Sankt Peterburg), Živko Andrijašević (Nikšić), Csaba Békés (Budapest), Rajko

Bratož (Ljubljana), Svetlozar Eldarov (Sofija), Toni Filiposki (Skopje), Aleksandar Fotić

(Beograd), Vladan Gavrilović (Novi Sad), Alojz Ivanišević (Wien),

Egidio Ivetić (Padova), Husnija Kamberović (Sarajevo), Karl Kaser (Graz),

Irina Ognyanova (Sofija), Géza Pálffy (Budapest), Ioan-Aurel Pop (Cluj),

Nade Proeva (Skopje), Alexios Savvides (Kalamata), Vlada Stanković (Beograd),

Ludwig Steindorff (Kiel), Peter Štih (Ljubljana)

Izvršni urednik za tuzemnu i inozemnu razmjenu /

Executive Editor for Publications Exchange

Martin Previšić

Tajnik uredništva / Editorial Board Assistant

Dejan Zadro

Adresa uredništva/Editorial Board address

Zavod za hrvatsku povijest, Filozofski fakultet Zagreb, Ivana Lučića 3, HR-10 000, Zagreb Tel. ++385 (0)1 6120191

Časopis izlazi jedanput godišnje / The Journal is published once a year

Časopis je u digitalnom obliku dostupan na / The Journal in digital form is accessible at

Portal znanstvenih časopisa Republike Hrvatske „Hrčak“ http://hrcak.srce.hr/radovi-zhp

Financijska potpora za tisak časopisa / The Journal is published with the support by Ministarstvo znanosti, obrazovanja i športa Republike Hrvatske

Časopis je indeksiran u sljedećim bazama / The Journal is indexed in the following databases: Directory of Open Access Journals, EBSCO, SCOPUS, ERIH PLUS, Emerging Sources Citation Index - Web of Science 


\title{
Naslovna stranica / Title page by Marko Maraković
}

\section{Grafičko oblikovanje i računalni slog / Graphic design and layout Marko Maraković}

\author{
Lektura / Language editors \\ Samanta Paronić (hrvatski / Croatian) \\ Edward Bosnar (engleski / English)
}

Tisak / Printed by

Tiskara Zelina, Sv. Ivan Zelina

Naklada / Issued

200 primjeraka / 200 copies

Ilustracija na naslovnici

Muza Klio (Alexander S. Murray, Manual of Mythology, London 1898)

Časopis je u digitalnom obliku dostupan na Portalu znanstvenih časopisa Republike Hrvatske ,Hrčak“ http://hrcak.srce.hr/radovi-zhp

The Journal is accessible in digital form at the Hrcak - Portal of scientific journals of Croatia http://hrcak.srce.hr/radovi-zhp 